Article

\title{
Economic Development and the World Bank
}

\author{
M. Rodwan Abouharb 1,*D and Erick Duchesne ${ }^{2}$ (D) \\ 1 Department of Political Science, University College London, London WC1H 9QU, UK \\ 2 Department of Political Science, University of Laval, Québec, QC G1V 0A6, Canada; \\ Erick.duchesne@pol.ulaval.ca \\ * Correspondence: m.abouharb@ucl.ac.uk
}

Received: 2 April 2019; Accepted: 13 May 2019; Published: 17 May 2019

\begin{abstract}
We contribute to the research stream examining the effects of World Bank lending programs on economic growth in developing economies. We contend that it is important to distinguish between the short-term effects and extended exposure of countries to these lending programs and also to assess the Bank's (late 1990s) reforms to improve the effectiveness of these programs in recipient countries to assess whether program lending has any positive impacts on economic growth. Our comparative cross-national findings using instrumental variables analysis to control for endogeneity between program participation and economic growth demonstrate that both the short-term and longer exposure to program lending worsens economic growth. We find no evidence that World Bank reforms improved economic growth rates in the post-reform (1999-2009) period. Our findings are robust to changes in model specifications and estimation techniques. Future research should examine whether these reforms had beneficial impacts in other societal areas affected by program lending.
\end{abstract}

Keywords: World Bank; international financial organizations; program lending; economic growth; economic development

\section{Introduction}

Since the early 1980s, the World Bank has used program lending (PL) ${ }^{1}$ as one of its main tools to promote economic development in the developing world. Relatively little research examines the economic growth consequences of the Bank's approach to development. The vast majority of research analyses the economic growth consequences of International Monetary Fund (IMF) activities. This article consolidates our understanding of the economic growth consequences of World Bank PL since the Bank's shift in policy in the early 1980s and whether the reforms in the late 1990s, discussed in more detail below, improved the Bank's record promoting economic growth in countries under these programs.

We make two novel contributions to the literature. Our first contribution is to assess the consequences of short-term and longer exposure to these programs on recipient countries' economic growth rates. We believe that the lack of both theoretical and empirical distinction between the short-term effects and the consequences of extended exposure to PL on economic growth has led to much confusion in the literature about whether program lending has a positive impact on participating countries' rates of economic growth. This is pertinent especially since even defenders of the program lending approach concede that, in the short-term, PL may worsen growth rates but that, over time and with greater exposure to these reforms, developing economies will grow more than if they had not undertaken these changes (Rogoff 2003). We elaborate why the economic effects of PL may differ in the

1 While the World Bank introduced Sectoral Adjustment loans in 1984 as the mechanism for structural adjustment, they are essentially the same as Structural Adjustment Agreements (SAAs) (Harrigan and Mosley 1991). Therefore, for the purpose of this article, we will refer to those structural adjustment programs as program lending (PL). 
short-term in comparison with extended exposure and quantitatively test our arguments. The second contribution is to investigate the economic growth consequences of institutional changes at the Bank in the late 1990s. These institutional changes were designed to improve the effectiveness of these programs in recipient countries. By extending our empirical analysis to $2009^{2}$, we believe that it is now possible to provide a quantitative appraisal of these reforms on economic growth.

Our analysis of 131 developing countries with a population of at least 500,000 covers the entire period (1981-2009), as well as the pre-reform (1981-1998), and post-reform (1999-2009) periods. We find that longer exposure to program lending significantly worsened economic growth rates in participant countries in each of these periods. We also find evidence that that short-term exposure to program lending significantly worsened economic growth rates over the entire period (1981-2009), as well as the pre-reform (1981-1998), and post-reform (1999-2009) periods. A mix of economic, political and demographic factors also provided important explanations for economic growth in developing countries. Our findings are robust to changes in the model and different estimation techniques, which we detail in the alternate specifications discussion.

The results from our analysis lead us to question the efficacy of the World Bank's program lending approach to encourage economic growth as a key linchpin for economic development. While the Bank remains one of the most important global development institutions our research indicates that not only has its approach to encouraging economic growth failed but also that these failures continue despite changes made in the late 1990s to make these programs more effective. For citizens living in countries under program lending conditions, there is little evidence that the Bank's approach improves their national economic conditions. Our results also provide additional support to critics of the Bank's approach to development. From a theory testing perspective, our results dispute arguments made by defenders of program lending (e.g., Rogoff 2003) that longer exposure to these programs will improve economic growth. We find no evidence that short-term exposure, longer exposure, pre-reform exposure or post-reform exposure to World Bank program lending encourages economic growth.

The article is organized as follows. The next section discusses the pertinent literature that examines the economic impacts of World Bank program lending and provides the basis for our first set of hypotheses examining the overall relationship between program lending and economic growth. We then narrow the discussion to examine the World Bank institutional reforms in the mid-to late 1990s and its implications for economic growth. This provides the theoretical underpinning for our second set of hypotheses. Section 3 presents our research design. Section 4 shows our results. The final section concludes.

\section{Theoretical Framework: Economic Consequences of the World Bank Lending Programs}

The debate over the effectiveness of foreign aid to foster economic growth spans several decades, but the financing gap model, based on the Harrod-Domar Growth model (Domar 1946; Harrod 1939), provides the backdrop to the contemporary dispute on aid efficiency. ${ }^{3}$ The financing gap model proposes that sufficient international aid, including WB loans, could promote investment in infrastructure and human capital, thereby increasing exports and inward investment as a tool to close the foreign exchange and saving gaps. Proponents of the model point out the positive record of small discrete development and emergency interventions (Riddell 2007, p. 170) that are often not congruent with the results of studies such as ours, evaluating the effects of more comprehensive programs.

In this paper, we side with authors who argue that "financing the gap" is insufficient to spur economic development and that aid effectiveness is contingent on the policy environment of the recipient (Burnside and Dollar 2000, 2004a, 2004b; see also Collier and Dollar 2002; Kenny 2008; Mallick and

\footnotetext{
The limit of available data.

The Harrod-Domar Growth model benefitted from subsequent refinements made by Chenery and Strout (1966) in their two-gap model of economic growth (the existence of a "savings gap" and a "foreign exchange or trade gap").
} 
Moore 2008; World Bank 1998). In short, aid can induce growth solely in countries with good fiscal, monetary and trade policies (Acemoglu and Robinson 2012). In extension, Wane notes that "aid agencies have the capacity to direct good aid even in bad environments by adopting an incentive system that only rewards good projects" (Wane 2004, p. 23). Other scholars view that aid effectiveness is conditional on some recipients' characteristics, but they disagree on which characteristics matter (see Kenny 2008, pp. 334-35; Wane 2004, p. 2). In contrast, some analysts argue that aid can be effective regardless of the public policies pursued by recipients (Clemens et al. 2006; Dalgaard et al. 2004; Hansen and Tarp 2000, 2001; Irandoust and Ericsson 2005). Yet, others find no consistent evidence that aid encourages economic growth, regardless of the circumstances and policies implemented (Rajan and Subramanian 2008; Easterly et al. 2004).

Scholars have also noted a lack of consensus on the aid-development nexus under the leadership of the World Bank (see among others Arndt et al. 2010; Bourguignon and Sundberg 2007). On one side, Butkiewicz and Yanikkaya (2005) and Marchesi and Sirtori (2011), assert that World Bank programs have a positive effect on growth. On the other side, Bird and Rowlands (2001), and Easterly (2005) find little support for such positive connection. These authors reinforce the findings of Dollar and Svensson (2000), who conclude that domestic political economy forces "influence strongly the success or failure of reform programs supported by adjustment loans. We find no evidence that any of the variables under the World Bank's control affect the probability of success of an adjustment loan" (p. 895). Some of these research findings indicate that discrepancies can be attributed to the "micro-macro paradox" (Mosley 1987, p. 139). ${ }^{4}$ Most micro-level studies accentuating qualitative assessments of specific projects or programs, tend to find that they are effective (Blackmon 2008; White 2007). On the contrary, most macro-level research, to which this article belongs, using large cross-national datasets, report that program lending has either no discernible or negative impacts on economic growth.

We hope to reconcile some of these mixed views by providing some theoretical improvements to the debate. First, we argue that it is necessary to differentiate between the short-term consequences of PL and the effects of greater exposure to PL on economic growth. Much of the foregoing literature has examined, when countries are under programs in a given year, what we define as the short-term effects of program lending (for example Vreeland 2003). Other research has made the case that these programs were often designed to make sustained changes to the economy that took place over time (Abouharb and Cingranelli 2007; Birdsall and Londoño 1997). Some research has examined the cumulative effects of IMF program and World Bank program lending and finds little positive effect on economic growth (Easterly 2005). Some research has evaluated the cumulative economic, social, and physical integrity rights effects of spending longer under World Bank, and IMF program lending (Abouharb and Cingranelli 2006, 2007, 2009). They find that countries which spend longer under these programs have lower life expectancies, reduced literacy rates, and worsened human rights records. Many of these worsened rights outcomes may slow subsequent rates of economic growth (e.g., Barro 1997) because they undermine some of the key drivers of economic development. In contrast, if defenders of these programs (e.g., Rogoff 2003) are correct, then we should expect that developing economies who have greater exposure to these reforms will over time grow more efficiently than if they had not undertaken these changes. For these reasons, we examine whether longer exposure to these programs had any benefits on recipient countries' economic growth rates. Differentiating between short-term effects and longer exposure to PL produces a more nuanced understanding of the relationship between these programs and economic growth.

Second, in addition to distinguishing between the short-term and longer exposure effects of PL, it is also important to unpack the economic growth consequences of reforms made by the Bank in the mid-to late 1990s, which were designed to improve the effectiveness of these programs in recipient countries. While recent econometric studies cover a variety of periods, none of them estimates the

4 For a skeptical view of the existence of the micro-macro paradox, see Arndt et al. (2010). 
effects of such loans up to $2009 .^{5}$ Extending the period of study to 2009 allows us to provide the most comprehensive updated analysis of these programs and to account for the Bank's reforms in the mid-to late 1990s. ${ }^{6}$

While there is a debate in the literature about whether these types of programs promote economic growth, we argue, along with others (Abouharb and Cingranelli 2007; Dreher 2006; Hutchison and Noy 2003; SAPRIN 2004; Rajan and Subramanian 2008; Vreeland 2003), that the most persuasive evidence is that PL has deleterious effects on economic growth. The mechanisms through which PL may impede growth range from deep government budget cuts (Mosley et al. 1995), harsh financial discipline (Abouharb and Cingranelli 2007), insufficient account of initial human and physical distribution of assets (Birdsall and Londoño 1997) and flawed economic liberalization policies governments enacted as part of many PL packages (Stiglitz 2002). ${ }^{7}$ PL may have led to soaring interest payments crowding out public investments in basic services and infrastructure (Abouharb and Cingranelli 2007, pp. 9-12). In addition, Feyzioglu et al. (1998, p. 30) point to an inherent difficulty in monitoring the conditions associated with a loan, as aid-recipient countries could reduce their own investments in the sector that receives aid and transfer them to other sectors of the budget. Another reason why aid effectiveness must be questioned stems from Rajan and Subramanian (2011)'s argument that foreign aid may induce a "Dutch disease" phenomenon, where production shifts from tradable goods and services towards non-tradable goods and services, thus putting upward pressure on the exchange rate of a recipient country, resulting in its decline of relative international competitiveness. ${ }^{8}$ These considerations lead us to cast some doubts on the positive relationship between World Bank PL and economic growth:

Hypothesis $\mathbf{1}$ (H1). In the short-term program lending worsens the recipient country's economic growth rate.

Hypothesis 2 (H2). Longer exposure to program lending worsens the recipient country's economic growth rate.

While these hypotheses represent our expectations over the entire period under examination, the Bank undertook major reforms in the late 1990s to try and improve the functioning of program lending as a tool for promoting development. Improving rates of economic growth remains key to the Bank's vision of reducing poverty in the developing World. We examine these reforms and their implications for economic growth next.

\section{World Bank Institutional Reforms in the Late 1990s}

Under the presidency of James Wolfensohn (1995-2005), the World Bank, in a joint effort with the IMF under the Comprehensive Development Framework (CDF), initiated a new agenda to make program lending more effective and help the Bank fulfil its role in alleviating poverty in the developing World. The new objectives came in reaction to mounting criticisms from all circles asserting that the Bank lacked any attention to the Voice for the World's Poor (Wolfensohn 2005). Virulent criticisms

5 Kilby (2009), who evaluates the influence of the United States on World Bank disbursements between 1984 and 2005 , comes closer to covering the same period as ours. Dreher et al. (2009) cover the longest period (1970-2004), another study (Marchesi and Sirtori 2011) focuses on a relatively long period (1982-2005), while Butkiewicz and Yanikkaya (2005) extend their analysis as far back as the 1970s (1975-1999). Most articles surveyed have a starting point in the 1980s: Dollar and Svensson (2000) focus on the years 1980-1995, Easterly (2003) evaluates the impact of structural adjustment on poverty for the years 1980-1998, the duration of two other studies is 1980-1999 (Easterly 2005; Montinola 2010) and finally, Guillaumont and Laajaj (2006) pay attention to the years 1981-2002. Wane (2004), and Cull and Effron (2008) consider the periods 1990-2002 and 1992-2003 respectively.

6 We are careful to include country, regional, and time fixed effects to limit the bias on our results from particular national economic shocks and regional economic changes, for example the 1997-1999 Asian financial crisis, as well as global economic changes such as the 2008 and 2009 recessions.

7 In a recent study, Bas and Stone (2014) argue that countries that are more interested in participating in IMF programs are the least likely to have favorable growth outcomes. Their hypothesis, based on an adverse selection model, could also be tested in future studies in the context of World Bank PL.

8 While their argument is built on foreign aid in general, it is plausible to believe that PL may prompt a similar phenomenon This constitutes fertile ground for future research. 
targeted the negative impact of international financial institutions (IFI) conditionality on economic growth (see among many Collier et al. 1997; Santiso 2001). While the reforms were not expressly designed to improve rates of economic growth per se, we should expect the Bank, if successful, to foster program recipients' economic growth in the post-reform period, since growth is often described as a key factor in the promotion of development. The first initiatives aimed at reducing poverty were the Participatory Poverty Assessments (PPAs) introduced in 1994. Armed with a global consultation with the poor in developing countries, their stated goal was to include the views of the less privileged in the Bank's policy making (Robb 2002). It is, however, the Heavily Indebted Poor Countries Initiative (HIPC) and the Enhanced Heavily Indebted Poor Countries Initiative (EHIPC), started in 1996 and 1999 respectively, that were set to have the largest impact on poverty reduction through debt relief and forgiveness. ${ }^{9}$ In order to benefit from the debt relief associated with these programs, recipient countries are required to fill Poverty Reduction Strategy Papers (PRSPs) conveying their own domestic poverty reduction strategies (Driscoll and Evans 2005). Introduced in 2001, the Poverty Reduction Support Credits (PRSCs) were intended to ease conditionality by helping countries implement comprehensive country-owned development strategies. PRSPs and PRSCs resulted in a better alignment between national development strategies and IFI adjustment lending, despite a few deficiencies (Independent Evaluation Group 2010, pp. 31-41). At first glance, these initial results raise hopes that the World Bank is on track to foster economic development and alleviate poverty.

A growing number of studies reviewed the abovementioned reforms undertaken by the World Bank in the mid-to late 1990s, which were designed to learn from the successes and failures of previous lending decisions (see among others, Blackmon 2008; Killick 2004; Marchesi and Sirtori 2011; Paloni and Zanardi 2006a; World Bank 2004; World Bank and International Monetary Fund 2004, 2005). Whereas many of the aforementioned studies provide necessary micro-level assessments of the reforms, this article constitutes, to our knowledge, the first macro-level study of the impact of the reforms on economic growth. ${ }^{10}$

In 2005, the World Bank issued a voluminous report, subtitled Learning from a Decade of Reform, assessing progresses made over the 1990s (World Bank 2005). According to Rodrik (2006), the report constitutes "a genuinely interesting document: it represents a mea culpa [sic] as well as a way forward" (p. 986). With our econometric analysis of the post-reform period, we are interested in the way forward, as mentioned by Rodrik. Did the World Bank reforms improve economic growth outcomes compared to the period prior to these changes? This is especially important as improved economic growth outcomes are one of the major linchpins of the Bank's development strategy in the developing world. More debt relief, which formed part of these reforms may have made it easier for HIPC recipients to jump-start development. These lower debt payments freed money for governments to spend on goods and services (and potentially to lower tax rates on individuals and businesses), all of which may also encourage businesses and individuals to spend and invest increasing domestic economic growth rates. According to Blackmon (2008), the World Bank initiatives were more likely to be successful than the IMF in implementing an agenda that addresses poverty as a societal and development issue. Her micro-level analysis led her to conclude that the reforms were successful in four out of the five countries she studied (Tajikistan, Albania, Vietnam, and Mozambique, Cambodia being the exception) where government and civil society were engaged in an active dialogue with the Bank (Blackmon 2008, pp. 195-96).

Despite Blackmon's positive conclusions, for critics of the reforms, the conditionality of the late 1990s was simply old wine in new bottles (Abouharb and Cingranelli 2009; Easterly 2006; Killick 2004;

9 The EHIPC was supplemented in 2005 by the Multilateral Debt Relief Initiative (MDRI), which allowed for 100\% relief on eligible debts by the World Bank, the IMF and the African Development Fund. Thirty-five HIPC and two non-HIPC countries have reached the completion point under EHIPC and received MDRI relief (International Monetary Fund 2013). While not all countries that received PL qualified for debt relief under (E)HIPC/MDRI, we find an important overlap between both programs. Data available from the authors.

10 In fairness, Knack et al. (2012) also provide some much needed econometric analysis of the World Bank reforms by concentrating on countries' graduation from the Bank for 1982 through 2012. 
Weeks 2006). These critiques tend to focus on the negative economic and governance consequences of budget cuts to central government spending in areas such as public health and education, de-regulation of different sectors of the economy and privatization of state assets, all reducing the size and scope of the state (Abouharb and Cingranelli 2007; SAPRIN 2004; Stiglitz 2002). The World Bank and International Monetary Fund have pressured loan recipient governments to rapidly privatize state assets, often with little regard for the transparency, fairness, and accountability of these processes (Stiglitz 2002). This approach to the sale of valuable state assets provided politicians with plenty of opportunities to engage in corrupt behavior, allowing their supporters to purchase these companies often at well below their market value: the privatization processes in Russia (Stiglitz 2002) and Mozambique (Hanlon 2004) provide two good examples of this type of state cronyism. Perhaps even more damaging is the critique that organizations such as the World Bank turned a blind eye to this corruption because of their own institutional agendas to keep lending (Stiglitz 2002; Hanlon 2004; Gamazo and Andrés 2018). In a startling admission, the World Bank, in a document entitled Strengthening Bank Group Engagement on Governance and Anti-Corruption, noted that it did not have the "required staffing, skills and incentives in governance to effect results-oriented changes at the front lines of Bank operations." (World Bank 2007, p. 10) The Bank's admission concerned their technical capacity to counter corrupt behaviors in loan recipient governments. Others argue that key supporters of the Bank such as the United Kingdom government do not explicitly make funding to partner countries conditional upon reducing corrupt behavior or the prosecution of corrupt individuals (Hanlon 2004). For example, the Foreign and Commonwealth Office (2018) have placed an emphasis on building capacity in countries with poor governance "to increase transparency and accountability ... improve countries legislative frameworks ... build capacity in state bodies ... strengthen countries commitments and political will to tackle corruption." If the approach taken by the Bank increases corruption, and its key backers remain reluctant to tackle that corruption directly, evidence indicates that the persistence of poor governance slows economic growth, impoverishes the majority of citizens, and shortens the lives of many people within these states (De Mesquita et al. 2005).

Examples also illustrate how the common provisions in program lending such as the privatization of states' assets often lead directly to worsened economic and social rights outcomes for most citizens. The consequences of worsened economic and social rights outcomes may also slow rates of economic growth by having negative consequences on important components of human capital such as the health and therefore productivity of citizens. Privatization of the provision of potable water is a particularly interesting case in point. Besides reducing the size of the state, it helps loan recipients balance their budgets, end subsidies, and is a step towards deregulation of the economy. Health professionals agree on the link between access to safe and affordable water and public health. According to one estimate, over two million children die each year of diarrhea, a disease related to the lack of access to clean water (Grusky 2001). More than one billion people lack access to clean drinking water and approximately 2.5 billion have no sanitary means for disposing of human waste (Grusky 2001). Despite this knowledge and these conditions, in the 1990s, the World Bank and IMF adopted a policy of water privatization and full-cost water pricing. The concern expressed by the Bank and Fund was that the world is running out of fresh water sources at an alarming rate and that conflict over what remains is inevitable. Also, the Bank argued, governments of poor countries, which often subsidized the cost of providing potable water to their populations, had failed to deliver water to their populations efficiently (Alexander 2005). Based on this logic, water privatization became a fairly common program lending provision negotiated by both the IMF and the Bank. A review of 40 randomly selected IMF loan agreements reached in 2000 revealed that the IMF included provisions for water privatization in 12 of them-Angola, Benin, Guinea Bissau, Honduras, Nicaragua, Niger, Panama, Rwanda, Sao Tome and Principe, Senegal, Tanzania, and Yemen (Grusky 2001). The consequences for public health were usually disastrous. In most cases, water users were almost immediately hit with rate hikes of $100 \%$ or more. Those who were unable to pay higher prices turned to less safe sources of drinking water with serious negative public health consequences. 
World Bank lending programs that reduce the size and scope of the state have been criticized because they result in public spending cuts on health, education, and social welfare provision, which are also important components of human capital, and play an key role in promoting economic growth (Abouharb and Cingranelli 2007; SAPRIN 2004; Vreeland 2003). The evidence indicates that these cuts have not only have made it more difficult for citizens to access health care and education, often because user fees have been introduced or increased but now public sector workers are also engaged in corrupt behavior to compensate for the drastic cuts in their salaries due to World Bank imposed austerity measures (see Rose-Ackerman 1997; Hanlon 2004; SAPRIN 2004). In contrast to the severe public spending cuts, these loans provide large inflows of money to plug holes in central government budgets, which sometimes arose because governments were engaged in corrupt practices. Loans from international financial institutions papered over these cracks (Hanlon 2004). In other cases, corrupt leaders simply used loans and financial support to pay off their opponents, maintain their supporters and provide for a lavish lifestyle at the expense of their citizens health and well-being. The ongoing support from various United States administrations as well as the leadership of the World Bank and IMF for Zaire under President Mobutu is a good example. This support continued despite numerous reports about his kleptocratic behavior, the blurring of state and personal finances throughout his period in power, as well as the impoverishment and repression of the Zarian people (Ndikumana and Boyce 1998). Senior figures at the World Bank and IMF were well aware of the scale of corruption early on during Mobutu's tenure of power. For example, the IMF appointed Erwin Blumenthal, a West German Banker, to lead an expatriate team at the Zarian Central Bank in 1978 and 1979 to improve economic management in the country. In a report, he noted that the President made little distinction between state coffers and his own personal expenses. In 1979 Blumenthal resigned from his position concluding that the "impossibility of control of frauds' meant that there was 'not any-I repeat any-chance on the horizon that the numerous creditors of Zaire will recoup their funds' (Blumenthal 1982, pp. 154-55). Despite this report, loans continued. The World Bank became the largest creditor to the Mobutu regime. The IMF also began lending to the regime despite strong opposition from within their own senior ranks (Ndikumana and Boyce 1998, p. 211). Mobutu was able to successfully court Western support by establishing Zaire as an anti-Communist bastion in central Africa, divvying up lucrative mineral concessions to foreign firms, while also having one of the most liberal foreign investment climates in Africa at the time (Ndikumana and Boyce 1998, pp. 210-12). The result was that the political appointees running these international financial institutions and their political masters turned a blind eye to his misrule impoverishing Africa's potentially richest state to the detriment of its long-suffering population.

The World Bank's own reports uncover mixed outcomes, some more successful than others subsequent to the reforms they implemented (Independent Evaluation Group 2006, 2010). Some of the criticisms levied at the PL reforms include inefficient redistribution of aid to HIPC countries from low-income-countries (Killick 2004), the inconsistencies of "high-profile" conditionality's (stabilization, trade policy, privatization and restructuring of the private sector) with national ownership of development strategies (Weeks 2006; Paloni and Zanardi 2006b), lack of feedback from recipient countries (Easterly 2006) and an increased reliance of high-risk programmatic lending in contrast to smaller absolute dangers of failure associated with project modes (Killick 2004). ${ }^{11}$ Killick (2004) also observes "the expansion of spending on social services to the neglect of wider growth and developmental priorities" (p. 8), which should have a negative impact on long-term growth.

Our research speaks to contrasting perspectives on the Bank, its role, and how we should evaluate its activities. Some work has argued that the wide range of development activities the Bank is involved in coupled with the expertise of Bank staff means that the institution has "tremendous policy influence" in partner countries' development policies (Clemens and Kremer 2016, p. 54). Perhaps not surprisingly, Clemens and Kremer (2016, p. 54) are skeptical about the value of research that simply assesses the

11 Killick (2004), also argues that program aid is burdened by higher transaction cost than specific projects. 
success of Bank policies with regression analysis that "use economic growth rates as the dependent variable and disbursements of aid as an explanatory variable will inevitably be quite misleading." We agree that cash disbursements relative to the size of loan recipients' economies are quite small (Clemens and Kremer 2016; Ravallion 2016) and that research which only took this approach would be liable to criticism. We side here with the acknowledgement of research to assess not only the poverty reduction outcomes of World Bank lending, but also try to establish the long-term consequences of the Bank's lending policies (Ravallion 2016, pp. 83-84). One of the key goals of program lending is to encourage economic growth to facilitate poverty reduction in developing economies. If the Bank's program lending approach has been successful in promoting economic growth, then this reflects positively on the Bank's policy expertise and influence to encourage developing countries to undertake the necessary policy changes. We agree with the Bank's laudable goals: by 2030 it wants to not only reduce extreme poverty, by decreasing the percentage of people living on "less than $\$ 1.90$ a day to no more than 3\%" but also to promote "shared prosperity by fostering the income growth of the bottom $40 \%$ for every country" (World Bank 2019). The question remains whether the World Bank PL approach actually encourages economic growth, a key linchpin in its goals of poverty alleviation. Confronted with inconclusive, contrasting and incomplete assessments of World Bank PL in the twenty-first century, we proceed with caution with the following hypotheses:

Hypothesis 3 (H3). Pre-reform, the short-term effects and longer exposure to program lending worsen rates of economic growth.

Hypothesis 4 (H4). Post-reform, the short-term effects and longer exposure to program lending improves rates of economic growth.

\section{Research Design}

We use a cross-national, annual time-series dataset utilizing the Correlates of War (2008) framework of 131 developing countries, with a population of at least 500,000 in 1981. We exclude OECD nations because they were not eligible for program lending.

We use two different approaches to measure PL implementation. The first is a running count of the time countries spent under PL for the entire period. It is an appropriate way to examine whether countries with greater exposure to PL reforms had better rates of economic growth. The alternate approach, similar to Przeworski and Vreeland's (2000) and Vreeland's (2003) analysis of IMF programs on economic growth, simply examines whether a country is under program lending. In this alternative, we use a dichotomous indicator of whether a country was under a World Bank PL or not each year. The second measure allows us to examine any short-term benefits of PL on economic growth. We provide details on both indicators below. For our entire period of analysis, the World Bank negotiated 556 PL with countries in our sample.

We account for a possible endogenous relationship between countries under World Bank PL and worsened rates of economic growth using an instrumental variable approach. In doing so, we follow the approach of studies that examined the impact of IMF lending on economic growth (Atoyan and Conway 2006; Bas and Stone 2014; Dreher 2006; Przeworski and Vreeland 2000; Vreeland 2003).

In our analysis, we are interested in utilizing an instrument (the excluded exogenous variable) that directly impacts going under World Bank program lending and is only indirectly related to changes in economic growth. We utilize a measure of a governments' dependent relationship with the United States (Hensel 2018) as our instrument for the following reasons. A considerable amount of research indicates the pivotal role that the United States plays in determining which governments are more likely to go under PL (Vreeland 2003; Stone 2004; Abouharb and Cingranelli 2006, 2007; Dreher 2006; Dreher et al. 2009; Dreher and Sturm 2012). The general argument made by the existing research is that governments which co-operate more with the United States (Vreeland 2003; Dreher 2006; Dreher et al. 2009; Dreher and Sturm 2012), are allied with the United States (Abouharb and Cingranelli 2006, 
2007) or have dependent relationships with the United States (Frey and Schneider 1986; Abouharb and Cingranelli 2004) are more likely to receive loans and these loans may come with fewer conditions (Stone 2004).

It is important to note that our instrument can be indirectly related to changes in economic growth, the exclusion restriction is that it must not be directly related to changes in economic growth. There is good reason to believe that co-operation with the United States may benefit governments in their pursuit of economic growth. Yet the evidence indicates that these mechanisms are indirect, for example through trade policy (Council of Economic Advisors 2015), bilateral aid packages (Tarnoff and Nowels 2005), and increased foreign direct investment (e.g., Borensztein et al. 1998). This discussion provides a reasonable expectation that a measure of co-operation with the United States could be an appropriate instrument. Given the discussion of the literature above, there are a few potential candidates that we could use as an instrument. However, for an instrument to be useful in an analysis, it must also pass a set of stringent diagnostic tests that our instrument is relevant and that it is also strongly correlated with the endogenous variable (program lending). Some research examined how countries which voted more often with the United States in the UN General Assembly received more World Bank program loans (Dreher and Sturm 2012). Other research examined how the U.S. rewarded support from temporary members of the UN Security Council with loans from the World Bank (Dreher et al. 2009). Finally, some research examined how allies of the United States were more likely to receive World Bank program loans (Abouharb and Cingranelli 2004). While these measures predicted going under PL, they did not pass our diagnostic tests of being both relevant and strongly correlated. For these reasons, we chose whether the country has a dependent relationship with the U.S. based upon Hensel's (2018) Issues Correlates of War (ICOW) Colonial History dataset as our instrument because it did pass our diagnostic tests of being both relevant and strongly correlated with our endogenous regressor (program lending). To be sure, had we used the other instruments, which did not pass these diagnostic tests, our results would have been similar to our single-stage analyses, which we discuss later. The included exogenous variables form the basis of our second-stage regression equation and are displayed in our results. These variables directly affect our economic growth outcomes and are automatically included as instruments (StataCorp 2015, p. 1119). ${ }^{12}$

$$
\begin{gathered}
\gamma_{i}=\Upsilon_{i} \beta_{1}+\alpha_{1 i}+\mu_{i} \\
\Upsilon_{i}=\alpha_{1 i} \Pi_{2}+\alpha_{2 i} \Pi_{2}+v_{i}
\end{gathered}
$$

Here, $\gamma_{i}$ is the dependent variable for the $i$ th observation $\Upsilon_{i}$ represents the endogenous regressor (World Bank program lending). $\alpha_{1 i}$ represents the included exogenous regressors (Log GDPPC, Inflation Rates, Banks Domestic Credit Lending, Total Debt Service \% GNI, Debt forgiveness, Net financial flows IBRD, Openness, Under IMF PL, Human Capital, Capital Stock Per Worker, Exchange Rates, Foreign Currency Reserves, Change in Population, Corruption, Bureaucratic Quality, Law and Order, Level of Democracy, Military Regimes, Workers Rights, Cold War, Civil War Incidence, Sub-Saharan Africa region, Latin America and Caribbean region, East Asia and Pacific region). $\alpha_{2 i}$ represents the excluded exogenous regressor (USA Dependent/Colonial Experience). $\alpha_{1 \mathrm{i}}$ and $\alpha_{2 \mathrm{i}}$ are collectively called the instruments and $\mu_{\mathrm{i}}$ and $v_{\mathrm{i}}$ are zero mean error terms and the correlations between $\mu_{\mathrm{i}}$ and the elements of $v_{\mathrm{i}}$ are presumably non-zero (StataCorp 2015, p. 1118).

We use two stage least squares (TSLS), which is an appropriate instrumental variables estimator for our measure of the number of years under World Bank PL, which we treat as our endogenous regressor. Given the variety of estimators appropriate for examining the number of years under PL, we follow Baum et al.'s (2007) advice and present results in our appendices from Limited Information Maximum

12 We estimated our models using STATA 14.1. We utilized the "ivreg2" (Baum et al. 2010) command to estimate our TSLS, LIML, GMM, and CUE models. We utilized the "treatreg" command to estimate our treatment regression equations. 
Likelihood Models (LIML), Generalized Methods of Moments Models (GMM), and Continuously Updated Estimator models (CUE). Consistent findings across these different estimators would provide us with greater confidence about the robust nature of our results. We utilize diagnostic tests to establish (a) that our key independent variable of theoretical interest (program lending) is endogenous to economic growth, (b) that our instrument is relevant, and (c) that our instrument is strongly correlated with the endogenous variable. ${ }^{13}$

For our short-term effects models that examine the effects of simply being under World Bank program lending, we need to use a different instrumental variable model that is appropriate for the dichotomous nature of the endogenous regressor (being under World Bank PL or not in a given year). In this case, we use a Treatment Regression model, which allows us to estimate the effect of an endogenously chosen binary treatment (being under World Bank PL or not in a given year) on another endogenous continuous variable (economic growth). The structure of the model is the same as that discussed above but in this case, we are predicting going under World Bank program lending and then its subsequent effect on economic growth. Below, we elaborate on the operationalization procedures used for the key independent and dependent variables to ensure replication.

\subsection{Variables}

\subsubsection{Number of Years under World Bank Program Lending}

Our numbers of years under World Bank PL variable is both a dependent variable in the first stage and an independent variable in the second stage of our model. This is a running count of the number of years under World Bank program lending. The measure comes from Abouharb and Cingranelli (2007) and is updated using individual country program lending information from the World Bank website.

Since most PL packages last for three years and research has determined that on average it takes eighteen months for implementation to affect the economy, the results of the adjustment process should appear in years two, three, and four of the loan period (Jayarajah et al. 1996). For this reason, the three years after loan receipt were coded as a "one". The year of negotiation was coded as a " 0 " unless a previously negotiated World Bank PL was still in effect that year. We generate a running count of the numbers of years under World Bank PL countries have spent during the period 1981-2009. Thus, the number can range in theory from 0-29. A value of ' 29 ' indicates that a country has been under PL for the entire period. The assumption here is that the longer a country has been under PL, the more it implements its provisions. This assumption is one followed by other studies on this topic (Przeworski and Vreeland 2000; Vreeland 2003).

\subsubsection{Under World Bank Program Lending or Not}

Our second measure is whether a country is under World Bank PL or not. This measure is our alternate dependent variable in the first stage and alternate independent variable in the second stage of our model. It estimates the short-term effects of going under World Bank program lending. This version closely resembles that used by Przeworski and Vreeland (2000) and Vreeland (2003) in their analysis of IMF programs on economic growth. We use a dichotomous indicator of the periods under program lending. Following the discussion above, years two, three, and four of any PL loan period are given a value of ' 1 ' and ' 0 ' otherwise. The major difference between this version and our longer exposure measure is that this indicator reflects the short-term effects of conditionality. Nevertheless, it is designed to capture the effects of these programs, since they would normally take a year at least to filter through to the economy as a whole. The measure also comes from Abouharb and Cingranelli (2007) and is updated using individual country PL information from the World Bank website.

13 Since our models include only one instrument, they are exactly identified and are by definition not over-identified, meaning that a Hansen J-statistic indicating whether a model is over-identified is unnecessary in these analyses. TSLS models are appropriate with the use of one instrument (StataCorp 2015). 


\subsubsection{Dependent Variable: Economic Growth}

Our key dependent variable, a measure of economic growth, comes from Penn World Tables 8.0 (Feenstra et al. 2013). It is the annual percentage change in GDP per Capita Constant 2005 Prices. Feenstra et al. (2013) recommend this measure as an appropriate dependent variable in studies that examine economic growth cross nationally over time. We generated this measure by lagging the original measure one year, and then calculating a percentage change from the annual difference.

\subsubsection{Control Variables}

Table 1 contains an overview of the variables selected for both stages of our analyses. We have discussed our choice of instruments and focus here on the economic growth stage of our analysis. To evaluate the impact of PL on economic growth of recipient countries, we use a conceptual framework similar to Abouharb and Cingranelli (2007), Dreher (2006), and Vreeland (2003). A variety of economic, international and domestic political factors as well as international financial institutional factors impact economic growth. ${ }^{14}$ Economic factors include the overall wealth and inflation rates of a country (Barro 2003), the role of domestic credit and human capital (Barro and Lee 2010) debt forgiveness (Clements et al. 2005), the amount of capital stock per worker (Butkiewicz and Yanikkaya 2005), and foreign currency reserves (Vreeland 2003). Political factors include the role of good governance, particularly better maintenance of the rule of law (Barro 1997), limiting corruption (Acemoglu et al. 2005; De Mesquita et al. 2005) and constraints on power holders usually through more democratic institutional mechanisms (Barro 1997; Acemoglu et al. 2005; De Mesquita et al. 2005) within a country and if it is a military-led regime (Barro 1997; Butkiewicz and Yanikkaya 2005; Vreeland 2003). We included the size of the population, which provides some indication about the size of the potential workforce and market within a country (Barro 2003). Domestic conflicts also have consequences lowering economic growth (Collier 2008). Finally, variation in trade within regions changes rates of economic growth and, in the context of PL, research has stressed the importance of accounting for the regions of: Sub-Saharan Africa, East Asia and Pacific, and also Latin America and the Caribbean (Butkiewicz and Yanikkaya 2005). In addition to estimating our models with these regional fixed effects, all our models include yearly fixed effects. We present descriptive statistics in Appendix A. Pairwise correlations (not presented) indicate that our Sub-Saharan Regional dummy is most highly correlated with our measure of human capital at 0.51 . However, Variance Inflation Factor (VIF) tests show that there are no problems of multicollinearity with our measure of Human Capital, which has a VIF score of 2.58 well below the threshold of 10 deemed to be problematic. ${ }^{15}$ We now discuss our results.

Table 1. Operationalization of Variables.

\begin{tabular}{ccc}
\hline Second-Stage Dependent Variable & Indicator & Source \\
\hline $\begin{array}{c}\text { Percentage change in GDP per } \\
\text { Capita }\end{array}$ & $\begin{array}{c}\text { Percentage change in GDP per capita at } \\
\text { constant 2005 prices }\end{array}$ & $\begin{array}{c}\text { Constructed from Penn World Tables (PWT) } \\
8.0 \text { (Feenstra et al. 2013) }\end{array}$ \\
\hline $\begin{array}{c}\text { Independent Variables } \\
\text { program lending(PL) }\end{array}$ & $\begin{array}{c}\text { Running count of years a country has } \\
\text { been under World Bank PL }\end{array}$ & $\begin{array}{c}\text { Abouharb and Cingranelli (2007) and } \\
\text { updated using World Bank (WB) website } \\
\text { program lending country reports } \\
\text { Abouharb and Cingranelli (2007) and } \\
\text { updated using WB website program } \\
\text { lending country reports }\end{array}$ \\
\hline
\end{tabular}

14 For an extensive discussion, see Abouharb and Cingranelli (2007).

15 We use the "collin" command in STATA 14.1 to conduct VIF tests. 
Table 1. Cont.

\begin{tabular}{|c|c|c|}
\hline Control Variables & & \\
\hline \multicolumn{3}{|l|}{ Economic } \\
\hline Log of GDP per Capita & $\begin{array}{l}\text { Log GDP per capita at constant } 2005 \\
\text { prices }\end{array}$ & $\begin{array}{c}\text { Constructed from PWT } 8.0 \\
\text { (Feenstra et al. 2013) }\end{array}$ \\
\hline Inflation & GDP deflator & $\begin{array}{l}\text { World Development Indicators (WDI) } \\
\text { (World Bank 2015) }\end{array}$ \\
\hline Domestic Credit & $\begin{array}{l}\text { Domestic credit provided by banking } \\
\text { sector \% of GDP }\end{array}$ & WDI (World Bank 2015) \\
\hline Total Debt Service & Total debt service $\%$ of GNI & WDI (World Bank 2015) \\
\hline Debt forgiveness & $\begin{array}{l}\text { Change in debt stock due to debt } \\
\text { forgiveness or reduction current U.S.\$. }\end{array}$ & WDI (World Bank 2015) \\
\hline Net Financial Flows & $\begin{array}{l}\text { Net financial flows International Bank } \\
\text { for Reconstruction and Development } \\
\text { (IBRD) }\end{array}$ & WDI (World Bank 2015) \\
\hline Openness & International trade \% of GDP & PWT 7.0 (Heston et al. 2011) \\
\hline Under IMF PL & '1' = Under IMF PL and ‘0’ otherwise & $\begin{array}{c}\text { Vreeland (2003) and updated using IMF } \\
\text { Annual Reports }\end{array}$ \\
\hline Human Capital & $\begin{array}{c}\text { Human capital index based on years of } \\
\text { schooling (Barro and Lee 2010) and } \\
\text { assumed returns }\end{array}$ & PWT 8.0 (Feenstra et al. 2013) \\
\hline Capital Stock per Worker & $\begin{array}{l}\text { Capital stock at current PPPs/number of } \\
\text { persons engaged in the workforce }\end{array}$ & $\begin{array}{l}\text { Constructed from PWT } 8.0 \\
\text { (Feenstra et al. 2013) }\end{array}$ \\
\hline Exchange Rates & Exchange rate to U.S.\$ & PWT 8.0 (Feenstra et al. 2013) \\
\hline Foreign Currency Reserves & Numbers of months of imports & WDI (World Bank 2015) \\
\hline Population change & $\begin{array}{l}\text { Annual percentage change in } \\
\text { population }\end{array}$ & Constructed from WDI (World Bank 2015) \\
\hline \multicolumn{3}{|l|}{ Political } \\
\hline Corruption & $\begin{array}{c}\text { 0-6 Measure; higher values indicate less } \\
\text { corruption within the political system, } \\
\text { especially demands for bribes, } \\
\text { payments, patronage and "favor for } \\
\text { favors" }\end{array}$ & PRS Group, ICRG (PRS Group 2019) \\
\hline Bureaucratic Quality & $\begin{array}{l}\text { 0-4 Measure; higher values indicate } \\
\text { higher quality of bureaucracy where } \\
\text { institutional strength and expertise } \\
\text { exists to govern without drastic changes } \\
\text { in policy or interruptions in government } \\
\text { services }\end{array}$ & PRS Group, ICRG (PRS Group 2019) \\
\hline Law and Order & $\begin{array}{l}\text { 0-6 Measure; higher values indicate } \\
\text { stronger and more impartial judiciary } \\
\text { and better observance of the law }\end{array}$ & PRS Group, ICRG (PRS Group 2019) \\
\hline Level of Democracy & 0-10 Democracy measure & POLITY (Marshall and Jaggers 2010) \\
\hline Military Regime & ' 1 ' if military regime and ' 0 ' otherwise & Geddes et al. (2012) \\
\hline Workers' Rights & $\begin{array}{c}0-2 \text { measure; } 0=\text { Frequent }(50+) \\
\text { violations, } 1=\text { Occasional }(1-49 \\
\text { instances), } 2=\text { None }\end{array}$ & $\begin{array}{l}\text { Cingranelli et al. (2014); CIRI Human } \\
\text { Rights Data Project (2014) }\end{array}$ \\
\hline Cold War & ' 1 ' = Cold War and '0' otherwise & Constructed \\
\hline Civil War Incidence & $\begin{array}{c}0=\text { No civil war, } 1=1000 \text { battle deaths } \\
\text { or more }\end{array}$ & Gleditsch et al. (2002); Strand et al. (2005) \\
\hline \multicolumn{3}{|l|}{ Regions } \\
\hline $\begin{array}{l}\text { Sub-Saharan Africa; Latin America } \\
\text { and Caribbean; East Asia and Pacific }\end{array}$ & World Bank Definition & WDI (World Bank 2015) \\
\hline \multicolumn{3}{|l|}{$\begin{array}{c}\text { First-Stage (World Bank PL) } \\
\text { Dependent Variable }\end{array}$} \\
\hline $\begin{array}{l}\text { USA Dependent/Colonial } \\
\text { Experience }\end{array}$ & $\begin{array}{c}\text { The rule of the most recent possessor } \\
\text { identifies the relationships under } \\
\text { examination }\end{array}$ & ICOW dataset (Hensel 2018) \\
\hline
\end{tabular}

\section{Results}

In Tables 2 and 3, we present the results from our instrumental variables models (TSLS and Treatment Regressions) and contrast those results with single-stage Ordinary Least Squares (OLS) models that do not account for endogeneity. We begin with a discussion of our first-stage diagnostic tests presented in the lower portion of Table 2. Recall that we use the diagnostic tests to establish (a) that our key independent variable of theoretical interest (program lending) is endogenous to economic 
growth, (b) that our instrument is relevant, and (c) that our instrument is strongly correlated with the endogenous variable.

Briefly, the results from our Durbin-Wu-Hausman diagnostic tests indicate that endogeneity exists between program lending and economic growth across all our TSLS models presented in Table 2 at the 0.01-level of confidence or higher and is best estimated by an instrumental variable approach. Second, the instruments are relevant in all of our TSLS models presented in Table 2 indicated by the significant Kleibergen-Paap rk LM statistic at the 0.001-level of confidence. Third we find that our instrument is strongly correlated with the endogenous variable indicated by the Kleibergen-Paap Wald F statistics, which ranges between 72.27 and 132.58, well above the threshold of 10, indicating that the models do not suffer from weak instrumentation (Staiger and Stock 1997). The comprehensive nature of these diagnostic tests gives us confidence that our specifications properly instrument the endogenous process that makes some states more likely to go under program lending.

In Tables 2 and 3, we now discuss the results from our instrumental regression models estimating the effects of program lending on economic growth over the entire 1981-2009 period. We undertake increasingly stringent tests of our argument. Beginning with a barebones model that just includes economic controls, we then add political controls, regional controls and finish by including only controls that were significant in the previous full model. We compare our TSLS models presented in Table 2 and Appendix $C$ where we present the effects of program lending on economic growth in the pre-reform (1981-1998) and post-reform (1999-2009) periods with those presented in Appendix B that utilize other instrumental variables estimators including the LIML, GMM, and CUE models. We contrast these findings with single-stage OLS models that do not control for endogeneity.

The TSLS results we present in Table 2 displayed across the first three columns indicate that spending more time under PL significantly worsens economic growth over the 1981-2009 period. In our full model that includes regional controls, for each additional year a country spent under program lending, its economy contracted by -0.49 per cent. ${ }^{16}$ Countries that were never under PL on average grew at a rate of 7.0 per cent ${ }^{17}$; those under PL for the mean period of time (just over three years) had a growth rate of about 5.4 per cent ${ }^{18}$; those under PL for one standard deviation above the mean (just over eight years) had a growth rate of 3 per cent ${ }^{19}$; finally, those under PL for the maximum period of time ( 25 years), their growth rates actually contracted by -5.3 per cent ${ }^{20}$. When we examine the results from the other instrumental variables estimators displayed in Appendix B, we find strong support for the findings presented in Table 2, indicating the negative effects of greater exposure on economic growth for the 1981-2009 period. The alternate specifications presented in Appendix B indicate that for each additional year a country spent under program lending, its economy contracted by -0.49 per cent. In contrast, our single-stage OLS results that do not account for endogeneity, displayed in Table 2, indicate that greater exposure to PL had no significant effect on economic growth. If this single-stage model had been our preferred estimation technique, we would have erroneously concluded that greater exposure to PL had no significant effect on economic growth over the 1981-2009 period, much like Killick's (1995) early work that wondered what all the fuss was about concerning the negative effects of these programs on economic growth.

\footnotetext{
Confidence intervals (C.I.) range from -0.73 to -0.26 per cent.

C.I. range from +5.5 to +8.5 per cent.

C.I. range from +4.7 to +6.1 per cent.

C.I. range from +2.5 to +3.5 per cent.

C.I. range from -9.7 to -0.9 per cent.
} 
Table 2. Two-Stage Least Squares: World Bank Program Lending and Its Effects on Economic Growth, 1981-2009, All Developing Countries.

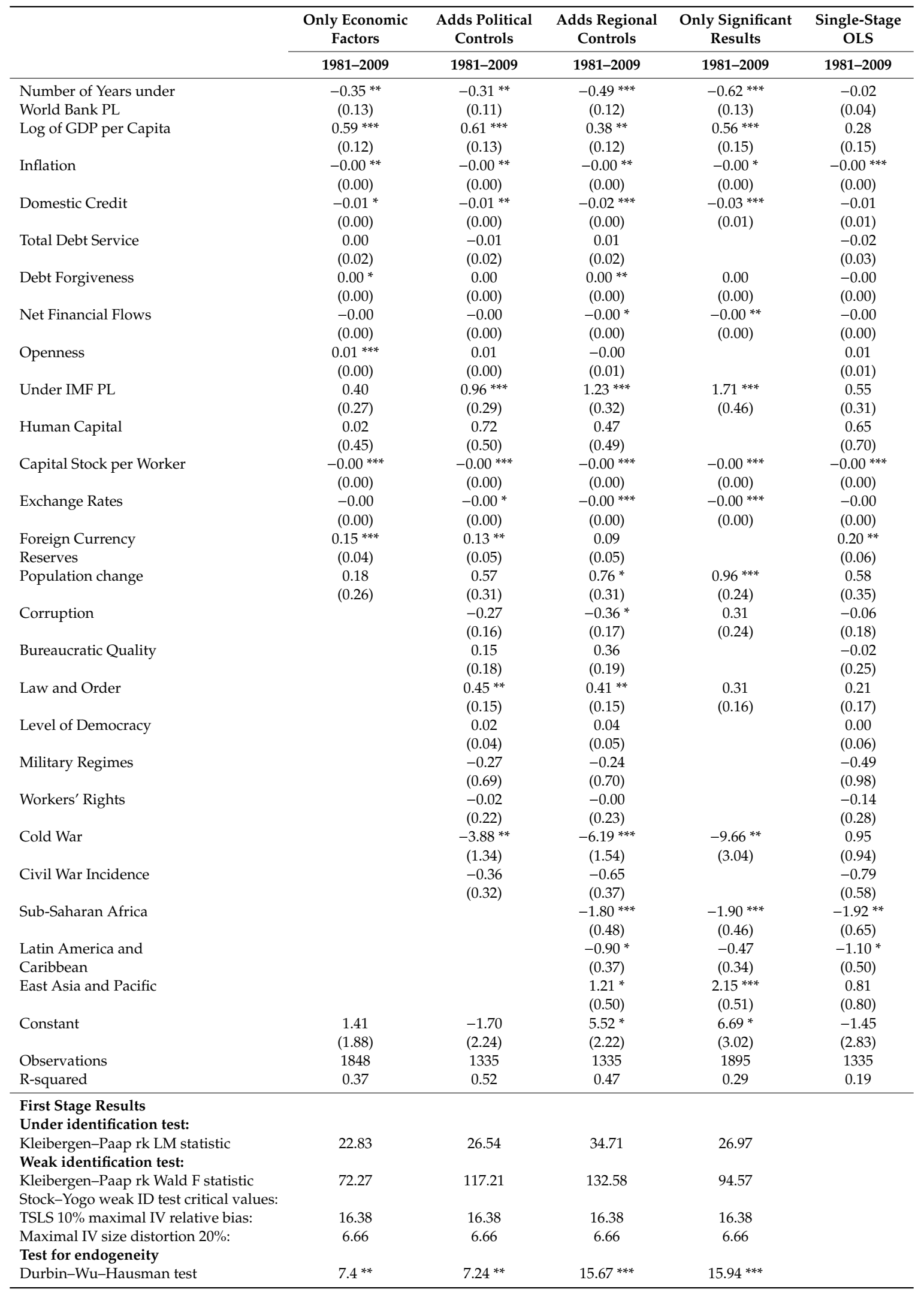

$p>\mid \mathrm{z} 0.05^{*}, 0.01 * *, 0.001^{* * *}$ All models were estimated with two-tailed significant tests and included time fixed effects. Robust standard errors in parentheses. 
Table 3. Treatment Regression: World Bank Program Lending and Its Effects on Economic Growth, 1981-2009, All Developing Countries.

\begin{tabular}{|c|c|c|c|c|c|}
\hline & $\begin{array}{l}\text { Only Economic } \\
\text { Factors }\end{array}$ & $\begin{array}{l}\text { Adds Political } \\
\text { Controls }\end{array}$ & $\begin{array}{l}\text { Adds Regional } \\
\text { Controls }\end{array}$ & $\begin{array}{l}\text { Only Significant } \\
\text { Results }\end{array}$ & $\begin{array}{l}\text { Single-Stage } \\
\text { OLS }\end{array}$ \\
\hline & 1981-2009 & 1981-2009 & 1981-2009 & 1981-2009 & 1981-2009 \\
\hline Under World Bank PL or & -0.14 & $-3.36^{*}$ & $-3.92^{* * *}$ & -0.83 & 0.42 \\
\hline Not & $(0.31)$ & $(1.48)$ & $(0.88)$ & $(0.55)$ & $(0.28)$ \\
\hline Log of GDP per Capita & $\begin{array}{c}0.40^{* * *} \\
(0.09)\end{array}$ & $\begin{array}{c}0.57^{* * *} \\
(0.12)\end{array}$ & $\begin{array}{c}0.30 * * \\
(0.11)\end{array}$ & $\begin{array}{c}0.07 \\
(0.06)\end{array}$ & $\begin{array}{l}0.26 \\
(0.15)\end{array}$ \\
\hline Inflation & $\begin{array}{l}-0.00 * * \\
(0.00)\end{array}$ & $\begin{array}{l}-0.00 * * \\
(0.00)\end{array}$ & $\begin{array}{l}-0.00 * * \\
(0.00)\end{array}$ & $\begin{array}{l}-0.00 * \\
(0.00)\end{array}$ & $\begin{array}{c}-0.00 * * * \\
(0.00)\end{array}$ \\
\hline Domestic credit & $\begin{array}{l}-0.00 \\
(0.00)\end{array}$ & $\begin{array}{c}-0.01 \text { * } \\
(0.00)\end{array}$ & $\begin{array}{c}-0.01 \text { ** } \\
(0.00)\end{array}$ & $\begin{array}{c}-0.01 \text { ** } \\
(0.00)\end{array}$ & $\begin{array}{l}-0.01 \\
(0.01)\end{array}$ \\
\hline Total Debt Service & $\begin{array}{l}-0.03 \\
(0.03)\end{array}$ & $\begin{array}{l}-0.03 \\
(0.03)\end{array}$ & $\begin{array}{l}-0.02 \\
(0.03)\end{array}$ & & $\begin{array}{l}-0.02 \\
(0.03)\end{array}$ \\
\hline Debt forgiveness & $\begin{array}{l}-0.00 \\
(0.00)\end{array}$ & $\begin{array}{l}-0.00 \\
(0.00)\end{array}$ & $\begin{array}{l}-0.00 \\
(0.00)\end{array}$ & & $\begin{array}{l}-0.00 \\
(0.00)\end{array}$ \\
\hline Net financial flows & $\begin{array}{c}0.00 \\
(0.00)\end{array}$ & $\begin{array}{c}0.00 \\
(0.00)\end{array}$ & $\begin{array}{l}-0.00 \\
(0.00)\end{array}$ & $\begin{array}{l}-0.00 \\
(0.00)\end{array}$ & $\begin{array}{l}-0.00 \\
(0.00)\end{array}$ \\
\hline Openness & $\begin{array}{l}0.02^{* * * *} \\
(0.00)\end{array}$ & $\begin{array}{l}0.02^{* * * *} \\
(0.00)\end{array}$ & $\begin{array}{c}0.01 \\
(0.00)\end{array}$ & & $\begin{array}{c}0.01 \\
(0.01)\end{array}$ \\
\hline Under IMF PL & $\begin{array}{l}-0.14 \\
(0.23)\end{array}$ & $\begin{array}{c}0.35 \\
(0.24)\end{array}$ & $\begin{array}{c}0.40 \\
(0.24)\end{array}$ & & $\begin{array}{c}0.36 \\
(0.32)\end{array}$ \\
\hline Human Capital & $\begin{array}{c}0.31 \\
(0.47)\end{array}$ & $\begin{array}{c}0.88 \\
(0.52)\end{array}$ & $\begin{array}{c}0.73 \\
(0.49)\end{array}$ & & $\begin{array}{c}0.65 \\
(0.70)\end{array}$ \\
\hline $\begin{array}{l}\text { Capital Stock Per } \\
\text { Worker }\end{array}$ & $-0.00^{* * *}$ & $-0.00^{* * * *}$ & $-0.00^{* * *}$ & $-0.00^{* * *}$ & $-0.00 * * *$ \\
\hline Exchange Rates & $\begin{array}{c}0.00 \\
(0.00)\end{array}$ & $\begin{array}{l}(0.00) \\
-0.00 \\
(0.00)\end{array}$ & $\begin{array}{l}(0.00) \\
-0.00 * * \\
(0.00)\end{array}$ & $\begin{array}{l}(0.00) \\
-0.00 \\
(0.00)\end{array}$ & $\begin{array}{l}(0.00) \\
-0.00 \\
(0.00)\end{array}$ \\
\hline Foreign Currency & $0.21^{* * *}$ & $0.20^{* * * *}$ & $0.19^{* * *}$ & $0.14^{* * *}$ & $0.20^{* * *}$ \\
\hline Reserves & $(0.04)$ & $(0.04)$ & $(0.04)$ & $(0.03)$ & $(0.06)$ \\
\hline Population change & $\begin{array}{c}0.13 \\
(0.25)\end{array}$ & $\begin{array}{c}0.49 \\
(0.30)\end{array}$ & $\begin{array}{l}0.64^{*} \\
(0.31)\end{array}$ & $\begin{array}{c}0.14 \\
(0.10)\end{array}$ & $\begin{array}{c}0.57 \\
(0.35)\end{array}$ \\
\hline Corruption & & $\begin{array}{l}-0.07 \\
(0.14)\end{array}$ & $\begin{array}{l}-0.04 \\
(0.14)\end{array}$ & & $\begin{array}{l}-0.04 \\
(0.18)\end{array}$ \\
\hline Bureaucratic Quality & & $\begin{array}{l}-0.09 \\
(0.16)\end{array}$ & $\begin{array}{l}-0.03 \\
(0.16)\end{array}$ & & $\begin{array}{l}-0.03 \\
(0.24)\end{array}$ \\
\hline Law and Order & & $\begin{array}{l}0.33^{* *} \\
(0.13)\end{array}$ & $\begin{array}{c}0.20 \\
(0.12)\end{array}$ & & $\begin{array}{c}0.19 \\
(0.17)\end{array}$ \\
\hline Level of Democracy & & $\begin{array}{c}0.01 \\
(0.04)\end{array}$ & $\begin{array}{c}0.01 \\
(0.04)\end{array}$ & & $\begin{array}{l}-0.00 \\
(0.06)\end{array}$ \\
\hline Military Regimes & & $\begin{array}{l}-0.64 \\
(0.68)\end{array}$ & $\begin{array}{l}-0.70 \\
(0.68)\end{array}$ & & $\begin{array}{l}-0.56 \\
(1.00)\end{array}$ \\
\hline Workers' Rights & & $\begin{array}{l}-0.17 \\
(0.20)\end{array}$ & $\begin{array}{l}-0.21 \\
(0.20)\end{array}$ & & $\begin{array}{l}-0.16 \\
(0.29)\end{array}$ \\
\hline Civil War Incidence & & $\begin{array}{l}-0.33 \\
(0.31)\end{array}$ & $\begin{array}{l}-0.67 * \\
(0.33)\end{array}$ & $\begin{array}{l}-0.94 * \\
(0.39)\end{array}$ & $\begin{array}{l}-0.77 \\
(0.59)\end{array}$ \\
\hline Cold War & & & $\begin{array}{l}-1.25 \\
(0.69)\end{array}$ & & $\begin{array}{c}1.09 \\
(0.94)\end{array}$ \\
\hline Sub-Saharan Africa & & & $\begin{array}{l}-1.87^{* * *} \\
(0.47)\end{array}$ & $\begin{array}{c}-1.47^{* * *} \\
(0.31)\end{array}$ & $\begin{array}{c}-1.88^{* *} \\
(0.65)\end{array}$ \\
\hline Latin America and & & & $-1.09 * *$ & $-1.12^{* * *}$ & $-1.06^{*}$ \\
\hline Caribbean & & & $(0.35)$ & $(0.24)$ & $(0.51)$ \\
\hline East Asia and Pacific & & & $\begin{array}{l}1.12 * * \\
(0.42)\end{array}$ & $\begin{array}{c}1.15^{* * * *} \\
(0.32)\end{array}$ & $\begin{array}{c}0.81 \\
(0.84)\end{array}$ \\
\hline Constant & $\begin{array}{l}-1.73 \\
(1.88)\end{array}$ & $\begin{array}{l}-3.67 \\
(2.50)\end{array}$ & $\begin{array}{c}1.68 \\
(2.03)\end{array}$ & $\begin{array}{c}5.55^{* * * *} \\
(1.25)\end{array}$ & $\begin{array}{l}-1.61 \\
(2.83)\end{array}$ \\
\hline Athro & 0.08 & 0.67 & 0.75 & 0.1 & -- \\
\hline Observations & 1848 & 1335 & 1335 & 2510 & 1335 \\
\hline
\end{tabular}

$p>\mid \mathrm{z} 0.05^{*}, 0.01^{* *}, 0.001^{* * *}$ All models were estimated with two-tailed significant tests and included time fixed effects. Robust standard errors in parentheses. 
In Table 3, we display the short-term effects of going under PL over the 1981-2009 period. We find a good deal of evidence that going under program lending worsens economic growth over the entire period, significant in both our model including political controls and our full model including regional controls. In contrast with Table 2, our short-term effects results are sensitive to model specification of only including significant results, they remain negative but are not longer significant. The results from our instrumental regression models provide strong support for hypothesis 2 that longer exposure to program lending worsens the recipient country's economic growth rates over the 1981-2009 period. We find a good amount of evidence for hypothesis 1, that in the short-term, program lending worsens the recipient country's economic growth rates over the 1981-2009 period. These findings provide support for previous research such as Dollar and Svensson (2000), Bird and Rowlands (2001), and Easterly (2005) about the inability of the Bank to facilitate economic growth in loan recipient countries.

Our overall results provide no evidence for supporters of these programs (Rogoff 2003), that even with longer exposure they will result in improved rates of economic growth. Our results overall also contrast those of Butkiewicz and Yanikkaya (2005), who found that the Bank was able to improve growth rates. In the following subsections, we provide more nuanced analysis to assess if the economic growth consequences of World Bank PL have varied over time.

Columns I-V and VI-X of Appendix C indicate the effects of longer periods under PL on economic growth, pre- and post-reform respectively. These results indicate that greater exposure to PL worsened economic growth over the 1981-1998 period in all four of our TSLS models, significant at the 0.05-level of confidence or higher. In our full model that includes regional controls for the 1981-1998 period, for each additional year a country spent under PL, its economy contracted by -0.64 per cent. ${ }^{21}$ If we turn to our alternate instrumental variables estimators in Appendix B, these provide consistent evidence for the negative effects of greater exposure to PL on economic growth over the 1981-1998 period across all three alternate estimators at the 0.05-level of confidence. Again, had we simply used a single-stage model, also presented in Appendix C, we would have found that going under World Bank programs did not significantly worsen economic growth rates. These results provide support for our third hypothesis that the pre-reform period would be associated with worsened rates of economic growth.

We examine Columns VI-X of Appendix C where our TSLS models indicate that in the post-reform period, greater exposure to PL was negatively associated with economic growth over the years 1999-2009, significant at the 0.05-level of confidence or higher in our full model and model containing only economic controls, but are sensitive to the model specification of only including significant results. In our full model that includes regional controls for the 1999-2009 period, for each additional year a country spent under PL, its economy contracted by -0.25 per cent. ${ }^{22}$ As before, when we turn to our alternate instrumental variables estimators in Appendix B, we find strong and consistent support across all three variants that greater exposure to PL in the 1999-2009 period worsened rates of economic growth at the 0.01-level of confidence. Again, had we used a single-stage model like that presented in Appendix C, the result indicated greater exposure to PL had no significant effect on economic growth in the post-reform period and would have led us to erroneously conclude that greater exposure to World Bank PL played no part in recipient countries worsening economic growth rates over the 1999-2009 period. ${ }^{23}$

Columns I-V and VI-X of Appendix D display the results for the short-term effects models in the pre- and post-reform period, respectively. The treatment regression results indicate that PL also had significant short-term negative effects on economic growth during the pre-reform (1981-1998) period

21 Confidence intervals range from -1.09 to -0.2 per cent.

22 Confidence intervals (C.I.) range from -0.41 to -0.09 per cent.

23 We also ran our models for the entire period with the addition of a post-reform dummy variable. This would reveal whether the post-reform period in general was associated with a different rate of economic growth. The dummy variable had a value of ' 1 ' for the post-reform 1999-2009 period and a '0' before. Our analysis indicated that the post-reform period was significantly associated with higher rates of economic growth at the 0.001-level of confidence or higher. Our measure of program lending, one indicating greater exposure, remained significant and negatively associated with economic growth rates at the 0.001-level of confidence. These results are available upon request from the authors. 
across our full model including regional controls and our model which included only economic and political controls. The model was sensitive to model specification where we only included significant results from our full model. In our full model that includes regional controls going under PL worsened growth rates by $-4.74 \%$, significant at the 0.001 -level of confidence. ${ }^{24}$ The results indicate significant negative associations between going under PL and worsened economic growth rates in the post-reform period (1999-2009) across all three treatment model specifications. In our full model that includes regional controls, going under PL worsened growth rates by $-2.99 \%$, significant at the 0.01 -level of confidence. ${ }^{25}$ These results support hypothesis 1 that program lending worsens rates of economic growth in the short-term. Yet, as before, the results do not support our fourth hypothesis that economic growth rates would improve in the post-reform period. Finally, had we also used a single-stage model (also displayed in Appendix D) to examine the short-term consequences of PL on economic growth, we would have incorrectly concluded that PL played no role in worsening rates of economic growth in the post-reform period.

The express purpose of these reforms was to successfully promote poverty reduction. The results indicate that they have failed to accomplish these macroeconomic objectives with little prospect of a commensurate reduction in poverty. This seems particularly problematic for the Bank, since the reforms were intended to learn from the mistakes of the past (Blackmon 2008) and improve the outcomes of these programs in developing countries.

The twenty-one instrumental model specifications from our core results presented in Tables 2 and 3 and Appendices B-D allow us to assess the consistent impact of various control variables on economic growth. We define our control variables as having a consistent effect if they were significant at the 0.05-level of confidence in more than half of the models presented and discuss them below. Wealthier countries, those with greater openness and higher levels of foreign currency reserves, are associated with faster rates of economic growth. In comparison, higher inflation rates, states with more domestic credit use, and those higher levels of capital stock were associated with a negative effect on economic growth. The latter two findings indicate that in states where the domestic banking sector provides more finance, and those with higher levels of capital stock, deserve further investigation and could reflect that more industrialized developing economies may tend to grow more slowly.

Next, we turn to the effects of political factors. While there is some evidence about the effects of political factors on economic growth, many of the models indicate no significant relationship. We found no evidence linking higher levels of democracy and economic growth. We found a negative association between military regimes and economic growth and a negative association between the Cold War period and economic growth, but only in a minority of the models. Our results from our regional dummies reflect variations in growth over this period not captured by our individual country year data or the inclusion of annual fixed effects. They indicate that the regions of Sub-Saharan Africa, Latin America and the Caribbean were associated with lower rates of economic growth in a majority of the models presented compared to East Asia and the Pacific. These results may well reflect arguments by the former Director General of the United Nations Food and Agricultural Organization Edouard Saouma that the 1980s in particular represented a lost decade of development for these regions (Ridley 1989). Our findings suggest that these overall negative trends may have continued throughout the period of this study.

\section{Discussion}

There is an important academic and policy debate about whether international aid encourages or discourages economic growth and what types of aid programs governments and international financial institutions should undertake (e.g., Sachs 2005; Easterly 2006). Economic growth is typically

24 C.I. range from -6.71 to -2.79 per cent.

25 C.I. range from -4.79 to -1.18 per cent. 
viewed as the linchpin for other aspects of economic development to take place (e.g., Barro 1997; 2003). There is plenty of debate about the role of governments to distribute and redistribute wealth in ways that reduce poverty (Donnelly 2003) and help realize individuals economic and social rights (Abouharb and Cingranelli 2007). What remains fundamental to many of these discussions about poverty reduction and economic and social rights promotion is the need for governments to generate revenue through taxes, which they can subsequently spend in the areas of health, education, and social welfare. It is much easier for governments to make these spending commitments when the economy grows and generates revenues through employment and taxation. Our research indicates that World Bank programs fail in promoting economic growth and subsequently make the attainment of poverty reduction and the realization of economic and social rights more difficult.

For policy makers interested in the ability of the World Bank to help alleviate poverty through its promotion of economic growth, our findings make for somber reading. While disappointing to read that the World Bank appears to be failing in its mission to promote economic growth, our results follow on from work by others on the negative effects of IMF program lending on economic growth (Vreeland 2003). Vreeland concludes that countries under IMF programs would have been better off if they had never gone under these programs in the first place.

Future research could examine the consequences of PL and the changes that took place in the late 1990s in the arena of social indicators. Focusing on economic growth does little to inform us about whether PL changes economic inequality in society. Second, PL may also affect gender equality in developing countries, with some arguing that those women are actually made worse off as a function of program lending (Elson 1991), and this deserves further examination. Finally, future studies must account for compliance with the terms of PL by recipient countries. We agree with Dreher (2006) and suggest that future studies of World Bank PL attempt to mimic his assessment of recipients' compliance with the conditions associated with IMF loans.

The intent of this project was to examine the effects of PL on economic growth. This is a profoundly important topic. While these programs are often unpopular in developing countries, governments pursue these policy changes under the advice of the World Bank, with the expectation that longer exposure to these programs will outweigh the potential short-term weight of the required adjustments. The results from this research indicate no support for such extended benefits of these programs on economic growth.

Author Contributions: Formal analysis, M.R.A. and E.D.; Writing-original draft, M.R.A. and E.D.; Writing一review \& editing, M.R.A. and E.D.

Funding: This research received no external funding.

Conflicts of Interest: The authors declare no conflict of interest. 


\section{Appendix A}

Table A1. Descriptive Statistics.

\begin{tabular}{|c|c|c|c|c|}
\hline Variable & Mean & $\begin{array}{l}\text { Standard } \\
\text { Deviation }\end{array}$ & Min & Max \\
\hline Economic Growth \% Change & 3.07 & 8.06 & -195.16 & 51.52 \\
\hline Number of Years under World Bank PL & 3.26 & 4.86 & 0 & 25 \\
\hline Under World Bank PL & 0.29 & 0.45 & 0 & 1 \\
\hline Log of GDP per Capita & 9.89 & 1.99 & 5.01 & 16.16 \\
\hline Inflation & 62.25 & 637.41 & -32.8 & $26,762.02$ \\
\hline Domestic Credit & 44.76 & 39.37 & -79.09 & 333.99 \\
\hline Total Debt Service & 5.55 & 5.73 & 0 & 112.08 \\
\hline Debt forgiveness & $3.29 \times 10^{7}$ & $2.71 \times 10^{8}$ & $-1.35 \times 10^{7}$ & $9.67 \times 10^{9}$ \\
\hline Net financial flows & $1.70 \times 10^{7}$ & $2.40 \times 10^{8}$ & $-4.67 \times 10^{9}$ & $4.21 \times 10^{9}$ \\
\hline Openness & 80.58 & 47.64 & 1.03 & 443.18 \\
\hline Under IMF PL & 0.36 & 0.48 & 0 & 1 \\
\hline Human Capital & 2.17 & 0.55 & 1.09 & 3.54 \\
\hline Capital Stock per Worker & $50,381.44$ & $63,635.52$ & 677.89 & $586,831.3$ \\
\hline Exchange Rates & 416.24 & 1533.13 & $4.17 \times 10^{-12}$ & $17,065.08$ \\
\hline Foreign Currency Reserves & 3.73 & 3.58 & -0.09 & 43.69 \\
\hline Population change & 1.77 & 2.88 & -124.51 & 36.25 \\
\hline Corruption & 2.61 & 1.06 & 0 & 6 \\
\hline Bureaucratic Quality & 1.77 & 1 & 0 & 4 \\
\hline Law and Order & 3.22 & 1.28 & 0 & 6 \\
\hline Level of Democracy & 3.67 & 3.78 & 0 & 10 \\
\hline Military Regimes & 0.07 & 0.26 & 0 & 1 \\
\hline Workers' Rights & 0.8 & 0.72 & 0 & 2 \\
\hline Cold War & 0.32 & 0.46 & 0 & 1 \\
\hline Civil War Incidence & 0.16 & 0.36 & 0 & 1 \\
\hline Sub-Saharan Africa & 0.31 & 0.46 & 0 & 1 \\
\hline Latin American and Caribbean & 0.22 & 0.41 & 0 & 1 \\
\hline East Asia and Pacific & 0.14 & 0.35 & 0 & 1 \\
\hline USA Dependent/Colonial Experience & 0.02 & 0.14 & 0 & 1 \\
\hline
\end{tabular}




\section{Appendix B}

Table A2. Alternate Instrumental Variables Regression Models: Limited Information Maximum Likelihood (LIML), Generalized Methods of Moments (GMM) and Continuously Updated Estimator (CUE) Models: World Bank Program Lending and Its Effects on Economic Growth, 1981-2009, All Developing Countries with Regional and Annual Fixed Effects.

\begin{tabular}{|c|c|c|c|c|c|c|c|c|c|}
\hline & \multicolumn{3}{|c|}{ LIML Models } & \multicolumn{3}{|c|}{ GMM Models } & \multicolumn{3}{|c|}{ CUE Models } \\
\hline & 1981-2009 & $1981-1998$ & 1999-2009 & 1981-2009 & 1981-1998 & 1999-2009 & 1981-2009 & 1981-1998 & 1999-2009 \\
\hline Number of Years under & $-0.49 * * *$ & $-0.64 * *$ & $-0.25 * *$ & $-0.49 * * *$ & $-0.64 * *$ & $-0.25 * *$ & $-0.49 * * *$ & $-0.64 * *$ & $-0.25 * *$ \\
\hline World Bank PL & $(0.12)$ & $(0.23)$ & $(0.08)$ & $(0.12)$ & $(0.23)$ & $(0.08)$ & $(0.12)$ & $(0.23)$ & $(0.08)$ \\
\hline \multirow{2}{*}{ Log of GDP per Capita } & $0.38^{* *}$ & $0.63 * *$ & 0.18 & $0.38 * *$ & $0.63 * *$ & 0.18 & $0.38 * *$ & $0.63 * *$ & 0.18 \\
\hline & $(0.12)$ & $(0.23)$ & $(0.12)$ & $(0.12)$ & $(0.23)$ & $(0.12)$ & $(0.12)$ & $(0.23)$ & $(0.12)$ \\
\hline \multirow[t]{2}{*}{ Inflation } & $-0.00 * *$ & $-0.00^{* * *}$ & -0.00 & $-0.00 * *$ & $-0.00^{* * *}$ & -0.00 & $-0.00^{* *}$ & $-0.00^{* * *}$ & -0.00 \\
\hline & $(0.00)$ & $(0.00)$ & $(0.02)$ & $(0.00)$ & $(0.00)$ & $(0.02)$ & $(0.00)$ & $(0.00)$ & $(0.02)$ \\
\hline \multirow[t]{2}{*}{ Domestic Credit } & $-0.02 * * *$ & $-0.03 * *$ & -0.01 & $-0.02 * * *$ & $-0.03 * *$ & -0.01 & $-0.02 * * *$ & $-0.03 * *$ & -0.01 \\
\hline & $(0.00)$ & $(0.01)$ & $(0.00)$ & $(0.00)$ & $(0.01)$ & $(0.00)$ & $(0.00)$ & $(0.01)$ & $(0.00)$ \\
\hline \multirow{2}{*}{ Total Debt Service } & 0.01 & -0.02 & 0.02 & 0.01 & -0.02 & 0.02 & 0.01 & -0.02 & 0.02 \\
\hline & $(0.02)$ & $(0.06)$ & $(0.02)$ & $(0.02)$ & $(0.06)$ & $(0.02)$ & $(0.02)$ & $(0.06)$ & $(0.02)$ \\
\hline \multirow[t]{2}{*}{ Debt Forgiveness } & $0.00^{* *}$ & 0.00 & 0.00 & $0.00 * *$ & 0.00 & 0.00 & $0.00 * *$ & 0.00 & 0.00 \\
\hline & $(0.00)$ & $(0.00)$ & $(0.00)$ & $(0.00)$ & $(0.00)$ & $(0.00)$ & $(0.00)$ & $(0.00)$ & $(0.00)$ \\
\hline \multirow[t]{2}{*}{ Net Financial Flows } & $-0.00 *$ & -0.00 & -0.00 & $-0.00 *$ & -0.00 & -0.00 & $-0.00 *$ & -0.00 & -0.00 \\
\hline & $(0.00)$ & $(0.00)$ & $(0.00)$ & $(0.00)$ & $(0.00)$ & $(0.00)$ & $(0.00)$ & $(0.00)$ & $(0.00)$ \\
\hline \multirow[t]{2}{*}{ Openness } & -0.00 & 0.01 & -0.01 & -0.00 & 0.01 & -0.01 & -0.00 & 0.01 & -0.01 \\
\hline & $(0.01)$ & $(0.01)$ & $(0.01)$ & $(0.01)$ & $(0.01)$ & $(0.01)$ & $(0.01)$ & $(0.01)$ & $(0.01)$ \\
\hline \multirow[t]{2}{*}{ Under IMF PL } & $1.23^{* * *}$ & $1.41^{* *}$ & $1.11^{* *}$ & $1.23^{* * *}$ & $1.41^{* *}$ & $1.11^{* *}$ & $1.23^{* * *}$ & $1.41 * *$ & $1.11^{* *}$ \\
\hline & $(0.32)$ & $(0.48)$ & $(0.35)$ & $(0.32)$ & $(0.48)$ & $(0.35)$ & $(0.32)$ & $(0.48)$ & $(0.35)$ \\
\hline \multirow[t]{2}{*}{ Human Capital } & 0.47 & -0.78 & $1.19^{* *}$ & 0.47 & -0.78 & $1.19^{* *}$ & 0.47 & -0.78 & $1.19^{* *}$ \\
\hline & $(0.49)$ & $(0.69)$ & $(0.43)$ & $(0.49)$ & $(0.69)$ & $(0.43)$ & $(0.49)$ & $(0.69)$ & $(0.43)$ \\
\hline Capital Stock per Worker & $\begin{array}{c}-0.00 * * * \\
(0.00)\end{array}$ & $\begin{array}{c}-0.00 * * * \\
(0.00)\end{array}$ & $\begin{array}{c}-0.00 * * * \\
(0.00)\end{array}$ & $\begin{array}{c}-0.00^{* * *} \\
(0.00)\end{array}$ & $\begin{array}{c}-0.00^{* * *} \\
(0.00)\end{array}$ & $\begin{array}{c}-0.00 * * * \\
(0.00)\end{array}$ & $\begin{array}{c}-0.00 * * * \\
(0.00)\end{array}$ & $\begin{array}{c}-0.00^{* * *} \\
(0.00)\end{array}$ & $\begin{array}{c}-0.00^{* * *} \\
(0.00)\end{array}$ \\
\hline \multirow[t]{2}{*}{ Exchange Rates } & $-0.00 * * *$ & $-0.00 * * *$ & $-0.00 *$ & $-0.00 * * *$ & $-0.00 * * *$ & $-0.00 *$ & $-0.00 * * *$ & $-0.00^{* * *}$ & $-0.00 *$ \\
\hline & $(0.00)$ & $(0.00)$ & $(0.00)$ & $(0.00)$ & $(0.00)$ & $(0.00)$ & $(0.00)$ & $(0.00)$ & $(0.00)$ \\
\hline Foreign Currency & 0.09 & $0.21 * *$ & 0.01 & 0.09 & $0.21 * *$ & 0.01 & 0.09 & $0.21 * *$ & 0.01 \\
\hline & $(0.05)$ & $(0.08)$ & $(0.06)$ & $(0.05)$ & $(0.08)$ & $(0.06)$ & $(0.05)$ & $(0.08)$ & $(0.06)$ \\
\hline \multirow{2}{*}{ Population change } & $0.76^{*}$ & $0.83 *$ & 0.34 & $0.76^{*}$ & $0.83 *$ & 0.34 & $0.76^{*}$ & $0.83 *$ & 0.34 \\
\hline & $(0.31)$ & $(0.38)$ & $(0.21)$ & $(0.31)$ & $(0.38)$ & $(0.21)$ & $(0.31)$ & $(0.38)$ & $(0.21)$ \\
\hline \multirow[t]{2}{*}{ Corruption } & $-0.36^{*}$ & -0.23 & -0.29 & $-0.36^{*}$ & -0.23 & -0.29 & $-0.36^{*}$ & -0.23 & -0.29 \\
\hline & $(0.17)$ & $(0.26)$ & $(0.18)$ & $(0.17)$ & $(0.26)$ & $(0.18)$ & $(0.17)$ & $(0.26)$ & $(0.18)$ \\
\hline \multirow[t]{2}{*}{ Bureaucratic Quality } & 0.36 & 0.40 & 0.04 & 0.36 & 0.40 & 0.04 & 0.36 & 0.40 & 0.04 \\
\hline & $(0.19)$ & $(0.26)$ & $(0.32)$ & $(0.19)$ & $(0.26)$ & $(0.32)$ & $(0.19)$ & $(0.26)$ & $(0.32)$ \\
\hline
\end{tabular}


Table A2. Cont.

\begin{tabular}{|c|c|c|c|c|c|c|c|c|c|}
\hline & \multicolumn{3}{|c|}{ LIML Models } & \multicolumn{3}{|c|}{ GMM Models } & \multicolumn{3}{|c|}{ CUE Models } \\
\hline & 1981-2009 & 1981-1998 & 1999-2009 & 1981-2009 & 1981-1998 & 1999-2009 & 1981-2009 & 1981-1998 & 1999-2009 \\
\hline Law and Order & $\begin{array}{l}0.41^{* *} \\
(0.15)\end{array}$ & $\begin{array}{l}-0.05 \\
(0.22)\end{array}$ & $\begin{array}{l}0.40^{*} \\
(0.16)\end{array}$ & $\begin{array}{l}0.41^{* *} \\
(0.15)\end{array}$ & $\begin{array}{l}-0.05 \\
(0.22)\end{array}$ & $\begin{array}{l}0.40^{*} \\
(0.16)\end{array}$ & $\begin{array}{l}0.41^{* *} \\
(0.15)\end{array}$ & $\begin{array}{l}-0.05 \\
(0.22)\end{array}$ & $\begin{array}{l}0.40 * \\
(0.16)\end{array}$ \\
\hline Level of Democracy & $\begin{array}{c}0.04 \\
(0.05)\end{array}$ & $\begin{array}{c}0.02 \\
(0.07)\end{array}$ & $\begin{array}{l}-0.03 \\
(0.05)\end{array}$ & $\begin{array}{c}0.04 \\
(0.05)\end{array}$ & $\begin{array}{c}0.02 \\
(0.07)\end{array}$ & $\begin{array}{l}-0.03 \\
(0.05)\end{array}$ & $\begin{array}{c}0.04 \\
(0.05)\end{array}$ & $\begin{array}{c}0.02 \\
(0.07)\end{array}$ & $\begin{array}{l}-0.03 \\
(0.05)\end{array}$ \\
\hline Military Regimes & $\begin{array}{l}-0.24 \\
(0.70)\end{array}$ & $\begin{array}{l}-0.84 \\
(0.82)\end{array}$ & $\begin{array}{l}-0.38 \\
(0.81)\end{array}$ & $\begin{array}{l}-0.24 \\
(0.70)\end{array}$ & $\begin{array}{l}-0.84 \\
(0.82)\end{array}$ & $\begin{array}{l}-0.38 \\
(0.81)\end{array}$ & $\begin{array}{l}-0.24 \\
(0.70)\end{array}$ & $\begin{array}{l}-0.84 \\
(0.82)\end{array}$ & $\begin{array}{l}-0.38 \\
(0.81)\end{array}$ \\
\hline Workers' Rights & $\begin{array}{l}-0.00 \\
(0.23)\end{array}$ & $\begin{array}{c}0.01 \\
(0.30)\end{array}$ & $\begin{array}{l}-0.05 \\
(0.28)\end{array}$ & $\begin{array}{l}-0.00 \\
(0.23)\end{array}$ & $\begin{array}{c}0.01 \\
(0.30)\end{array}$ & $\begin{array}{l}-0.05 \\
(0.28)\end{array}$ & $\begin{array}{l}-0.00 \\
(0.23)\end{array}$ & $\begin{array}{c}0.01 \\
(0.30)\end{array}$ & $\begin{array}{l}-0.05 \\
(0.28)\end{array}$ \\
\hline Civil War Incidence & $\begin{array}{l}-0.65 \\
(0.37)\end{array}$ & $\begin{array}{c}-1.48^{* *} \\
(0.54)\end{array}$ & $\begin{array}{c}0.17 \\
(0.37)\end{array}$ & $\begin{array}{l}-0.65 \\
(0.37)\end{array}$ & $\begin{array}{c}-1.48^{* *} \\
(0.54)\end{array}$ & $\begin{array}{c}0.17 \\
(0.37)\end{array}$ & $\begin{array}{l}-0.65 \\
(0.37)\end{array}$ & $\begin{array}{c}-1.48^{* *} \\
(0.54)\end{array}$ & $\begin{array}{c}0.17 \\
(0.37)\end{array}$ \\
\hline Sub-Saharan Africa & $\begin{array}{c}-1.80 * * * \\
(0.48)\end{array}$ & $\begin{array}{c}-1.59^{*} \\
(0.72)\end{array}$ & $\begin{array}{c}-1.45^{* * *} \\
(0.44)\end{array}$ & $\begin{array}{c}-1.80^{* * *} \\
(0.48)\end{array}$ & $\begin{array}{c}-1.59^{*} \\
(0.72)\end{array}$ & $\begin{array}{c}-1.45^{* * *} \\
(0.44)\end{array}$ & $\begin{array}{c}-1.80 * * * \\
(0.48)\end{array}$ & $\begin{array}{c}-1.59 * \\
(0.72)\end{array}$ & $\begin{array}{c}-1.45^{* * *} \\
(0.44)\end{array}$ \\
\hline $\begin{array}{c}\text { Latin America and } \\
\text { Caribbean }\end{array}$ & $\begin{array}{c}-0.90 * \\
(0.37)\end{array}$ & $\begin{array}{c}0.02 \\
(0.56)\end{array}$ & $\begin{array}{c}-1.29 * * \\
(0.41)\end{array}$ & $\begin{array}{c}-0.90 \text { * } \\
(0.37)\end{array}$ & $\begin{array}{c}0.02 \\
(0.56)\end{array}$ & $\begin{array}{c}-1.29 * * \\
(0.41)\end{array}$ & $\begin{array}{c}-0.90 * \\
(0.37)\end{array}$ & $\begin{array}{c}0.02 \\
(0.56)\end{array}$ & $\begin{array}{c}-1.29 * * \\
(0.41)\end{array}$ \\
\hline East Asia and Pacific & $\begin{array}{l}1.21^{*} \\
(0.50)\end{array}$ & $\begin{array}{l}2.03 * * \\
(0.78)\end{array}$ & $\begin{array}{c}0.64 \\
(0.46)\end{array}$ & $\begin{array}{l}1.21^{*} \\
(0.50)\end{array}$ & $\begin{array}{l}2.03^{* *} \\
(0.78)\end{array}$ & $\begin{array}{c}0.64 \\
(0.46)\end{array}$ & $\begin{array}{l}1.21 * \\
(0.50)\end{array}$ & $\begin{array}{l}2.03 * * \\
(0.78)\end{array}$ & $\begin{array}{c}0.64 \\
(0.46)\end{array}$ \\
\hline Observations & 1335 & 779 & 556 & 1335 & 779 & 556 & 1335 & 779 & 556 \\
\hline R-squared & 0.47 & 0.34 & 0.75 & 0.47 & 0.34 & 0.75 & 0.47 & 0.34 & 0.75 \\
\hline $\begin{array}{c}\text { First Stage Results } \\
\text { Under identification test: }\end{array}$ & & & & & & & & & \\
\hline $\begin{array}{l}\text { Kleibergen-Paap rk LM statistic. } \\
\text { Weak identification test: }\end{array}$ & $34.7^{* * *}$ & $19.1^{* * *}$ & $16.4^{* * *}$ & $34.7^{* * *}$ & $19.1^{* * *}$ & $16.4^{* * *}$ & $34.7^{* * *}$ & $19.1^{* * *}$ & $16.4^{* * *}$ \\
\hline $\begin{array}{c}\text { Kleibergen-Paap rk Wald F statistic } \\
\text { Stock-Yogo weak ID test critical values: }\end{array}$ & 132.6 & 51.9 & 51.7 & 132.6 & 51.9 & 51.7 & 132.6 & 51.9 & 51.7 \\
\hline $10 \%$ maximal LIML size: & 16.38 & 16.38 & 16.38 & & -- & -- & -- & -- & -- \\
\hline $10 \%$ maximal IV relative bias: & -- & -- & -- & 16.38 & 16.38 & 16.38 & 16.38 & 16.38 & 16.38 \\
\hline $\begin{array}{l}\text { Maximal IV size distortion } 20 \%: \\
\text { Test for endogeneity }\end{array}$ & 6.66 & 6.66 & 6.66 & 6.66 & 6.66 & 6.66 & 6.66 & 6.66 & 6.66 \\
\hline Durbin-Wu-Hausman test & $15.7^{* * *}$ & $9.9^{* *}$ & $6.6^{* *}$ & $15.7^{* * *}$ & $9.9^{* *}$ & $6.6^{* *}$ & $15.7^{* * *}$ & $9.9 * *$ & $6.6^{* *}$ \\
\hline
\end{tabular}




\section{Appendix C}

Table A3. Two-Stage and Single-Stage Least Squares: World Bank Program Lending and Its Effects on Economic Growth, Pre-and Post-Reform Periods, All Developing Countries with Regional and Annual Fixed Effects.

\begin{tabular}{|c|c|c|c|c|c|c|c|c|c|c|}
\hline & \multicolumn{5}{|c|}{ Pre-Reform Period } & \multicolumn{5}{|c|}{ Post-Reform Period } \\
\hline & 1981-1998 & 1981-1998 & 1981-1998 & 1981-1998 & 1981-1998 & 1999-2009 & 1999-2009 & 1999-2009 & 1999-2009 & 1999-2009 \\
\hline & $\begin{array}{c}\text { Only Econ } \\
\text { Factors }\end{array}$ & $\begin{array}{l}\text { Adds Pol } \\
\text { Controls }\end{array}$ & $\begin{array}{l}\text { Adds Reg } \\
\text { Controls }\end{array}$ & $\begin{array}{c}\text { Only Sign. } \\
\text { Results }\end{array}$ & $\begin{array}{l}\text { Single-Stage } \\
\text { OLS }\end{array}$ & $\begin{array}{c}\text { Only Econ } \\
\text { Factors }\end{array}$ & $\begin{array}{c}\text { Adds Pol } \\
\text { Controls }\end{array}$ & $\begin{array}{c}\text { Adds Reg } \\
\text { Controls }\end{array}$ & $\begin{array}{c}\text { Only Sign. } \\
\text { Results }\end{array}$ & $\begin{array}{c}\text { Single-Stage } \\
\text { OLS }\end{array}$ \\
\hline Number of Years & $-0.55^{*}$ & $-0.40 *$ & $-0.64^{* *}$ & $-0.65^{* *}$ & 0.06 & $-0.10 *$ & -0.11 & $-0.25^{* *}$ & 0.02 & -0.03 \\
\hline Under WB PL & $(0.24)$ & $(0.19)$ & $(0.23)$ & $(0.24)$ & $(0.07)$ & $(0.04)$ & $(0.07)$ & $(0.08)$ & $(0.05)$ & $(0.04)$ \\
\hline Log of GDP per & $0.82^{* * *}$ & $0.91^{* * *}$ & $0.63^{* *}$ & $0.29 *$ & 0.30 & $0.22 *$ & $0.28^{*}$ & 0.18 & & 0.15 \\
\hline Capita & $(0.18)$ & $(0.21)$ & $(0.23)$ & $(0.14)$ & $(0.22)$ & $(0.11)$ & $(0.11)$ & $(0.12)$ & & $(0.16)$ \\
\hline \multirow{2}{*}{ Inflation } & $-0.00^{* *}$ & $-0.00 * *$ & $-0.00^{* * *}$ & $-0.00^{* *}$ & $-0.00^{* * *}$ & 0.03 & 0.00 & -0.00 & & 0.00 \\
\hline & $(0.00)$ & $(0.00)$ & $(0.00)$ & $(0.00)$ & $(0.00)$ & $(0.02)$ & $(0.02)$ & $(0.02)$ & & $(0.02)$ \\
\hline \multirow[t]{2}{*}{ Domestic Credit } & -0.01 & -0.01 & $-0.03 * *$ & -0.00 & -0.02 & -0.00 & -0.00 & -0.01 & & -0.00 \\
\hline & $(0.01)$ & $(0.01)$ & $(0.01)$ & $(0.00)$ & $(0.01)$ & $(0.00)$ & $(0.00)$ & $(0.00)$ & & $(0.01)$ \\
\hline Total Debt & -0.00 & -0.05 & -0.02 & & $-0.12 *$ & 0.01 & 0.01 & 0.02 & & 0.01 \\
\hline Service & $(0.06)$ & $(0.06)$ & $(0.06)$ & & $(0.05)$ & $(0.02)$ & $(0.02)$ & $(0.02)$ & & $(0.02)$ \\
\hline Debt & 0.00 & 0.00 & 0.00 & & 0.00 & 0.00 & 0.00 & 0.00 & & 0.00 \\
\hline Forgiveness & $(0.00)$ & $(0.00)$ & $(0.00)$ & & $(0.00)$ & $(0.00)$ & $(0.00)$ & $(0.00)$ & & $(0.00)$ \\
\hline Net Financial & -0.00 & -0.00 & -0.00 & & 0.00 & -0.00 & -0.00 & -0.00 & & -0.00 \\
\hline Flows & $(0.00)$ & $(0.00)$ & $(0.00)$ & & $(0.00)$ & $(0.00)$ & $(0.00)$ & $(0.00)$ & & $(0.00)$ \\
\hline \multirow[t]{2}{*}{ Openness } & $0.03^{* * *}$ & $0.02 *$ & 0.01 & & 0.01 & 0.00 & 0.01 & -0.01 & & -0.00 \\
\hline & $(0.01)$ & $(0.01)$ & $(0.01)$ & & $(0.01)$ & $(0.00)$ & $(0.00)$ & $(0.01)$ & & $(0.01)$ \\
\hline \multirow[t]{2}{*}{ Under IMF PL } & 0.27 & $1.07^{*}$ & $1.41^{* *}$ & 0.35 & 0.66 & 0.53 & $0.91 * *$ & $1.11^{* *}$ & 0.55 & 0.65 \\
\hline & $(0.36)$ & $(0.42)$ & $(0.48)$ & $(0.38)$ & $(0.41)$ & $(0.28)$ & $(0.33)$ & $(0.35)$ & $(0.35)$ & $(0.36)$ \\
\hline Human & -0.71 & -0.34 & -0.78 & & -0.43 & 0.52 & $1.15^{* *}$ & $1.19^{* *}$ & $-0.86^{*}$ & 1.20 \\
\hline Capital & $(0.59)$ & $(0.66)$ & $(0.69)$ & & $(0.88)$ & $(0.39)$ & $(0.41)$ & $(0.43)$ & $(0.37)$ & $(0.66)$ \\
\hline Capital Stock & $-0.00^{* * *}$ & $-0.00^{* * *}$ & $-0.00^{* * *}$ & $-0.00 * * *$ & $-0.00 * * *$ & $-0.00 * *$ & $-0.00^{* * *}$ & $-0.00^{* * *}$ & 0.00 & $-0.00^{* *}$ \\
\hline per Worker & $(0.00)$ & $(0.00)$ & $(0.00)$ & $(0.00)$ & $(0.00)$ & $(0.00)$ & $(0.00)$ & $(0.00)$ & $(0.00)$ & $(0.00)$ \\
\hline Exchange & -0.00 & -0.00 & $-0.00^{* * *}$ & -0.00 & -0.00 & $0.00^{* *}$ & -0.00 & $-0.00 *$ & 0.00 & -0.00 \\
\hline Rates & $(0.00)$ & $(0.00)$ & $(0.00)$ & $(0.00)$ & $(0.00)$ & $(0.00)$ & $(0.00)$ & $(0.00)$ & $(0.00)$ & $(0.00)$ \\
\hline Foreign Currency & $0.24^{* * *}$ & $0.26^{* * *}$ & $0.21 * *$ & $0.17^{* * *}$ & $0.32 * * *$ & $0.09 *$ & 0.07 & 0.01 & & 0.09 \\
\hline Reserves & $(0.06)$ & $(0.07)$ & $(0.08)$ & $(0.05)$ & $(0.08)$ & $(0.04)$ & $(0.05)$ & $(0.06)$ & & $(0.06)$ \\
\hline Population & 0.19 & $0.79 *$ & $0.83^{*}$ & 0.25 & $0.78^{*}$ & 0.03 & -0.01 & 0.34 & & 0.14 \\
\hline change & $(0.30)$ & $(0.38)$ & $(0.38)$ & $(0.19)$ & $(0.36)$ & $(0.17)$ & $(0.20)$ & $(0.21)$ & & $(0.25)$ \\
\hline \multirow{2}{*}{ Corruption } & & -0.04 & -0.23 & & 0.20 & & $-0.37 *$ & -0.29 & & -0.24 \\
\hline & & $(0.24)$ & $(0.26)$ & & $(0.30)$ & & $(0.17)$ & $(0.18)$ & & $(0.23)$ \\
\hline Bureaucratic & & 0.06 & 0.40 & & 0.18 & & -0.17 & 0.04 & & -0.38 \\
\hline Quality & & $(0.22)$ & $(0.26)$ & & $(0.33)$ & & $(0.29)$ & $(0.32)$ & & $(0.31)$ \\
\hline \multirow[t]{2}{*}{ Law and Order } & & 0.00 & -0.05 & & -0.03 & & $0.43^{* *}$ & $0.40^{*}$ & 0.25 & 0.19 \\
\hline & & $(0.21)$ & $(0.22)$ & & $(0.20)$ & & $(0.15)$ & $(0.16)$ & $(0.18)$ & $(0.20)$ \\
\hline
\end{tabular}


Table A3. Cont.

\begin{tabular}{|c|c|c|c|c|c|c|c|c|c|c|}
\hline & \multicolumn{5}{|c|}{ Pre-Reform Period } & \multicolumn{5}{|c|}{ Post-Reform Period } \\
\hline & $\begin{array}{c}1981-1998 \\
\text { Only Econ } \\
\text { Factors }\end{array}$ & $\begin{array}{c}\text { 1981-1998 } \\
\text { Adds Pol } \\
\text { Controls }\end{array}$ & $\begin{array}{c}\text { 1981-1998 } \\
\text { Adds Reg } \\
\text { Controls }\end{array}$ & $\begin{array}{c}\text { 1981-1998 } \\
\text { Only Sign. } \\
\text { Results }\end{array}$ & $\begin{array}{l}\text { 1981-1998 } \\
\text { Single-Stage } \\
\text { OLS }\end{array}$ & $\begin{array}{c}\text { 1999-2009 } \\
\text { Only Econ } \\
\text { Factors }\end{array}$ & $\begin{array}{c}\text { 1999-2009 } \\
\text { Adds Pol } \\
\text { Controls }\end{array}$ & $\begin{array}{c}\text { 1999-2009 } \\
\text { Adds Reg } \\
\text { Controls }\end{array}$ & $\begin{array}{c}\text { 1999-2009 } \\
\text { Only Sign. } \\
\text { Results }\end{array}$ & $\begin{array}{c}\text { 1999-2009 } \\
\text { Single-Stage } \\
\text { OLS }\end{array}$ \\
\hline Level of & & 0.06 & 0.02 & & -0.03 & & -0.08 & -0.03 & & -0.05 \\
\hline Democracy & & $(0.06)$ & $(0.07)$ & & $(0.07)$ & & $(0.05)$ & $(0.05)$ & & $(0.07)$ \\
\hline Military & & -0.33 & -0.84 & & -0.42 & & -0.71 & -0.38 & & $-1.70 *$ \\
\hline Regimes & & $(0.77)$ & $(0.82)$ & & $(1.05)$ & & $(0.78)$ & $(0.81)$ & & $(0.69)$ \\
\hline Workers' Rights & & 0.09 & 0.01 & & -0.08 & & -0.08 & -0.05 & & -0.12 \\
\hline & & $(0.29)$ & $(0.30)$ & & $(0.32)$ & & $(0.27)$ & $(0.28)$ & & $(0.32)$ \\
\hline Cold War & & $\begin{array}{l}-1.02 \\
(1.30)\end{array}$ & $\begin{array}{l}-2.58 \\
(1.50)\end{array}$ & & $\begin{array}{c}1.88 \\
(0.99)\end{array}$ & & & & & \\
\hline Civil War & & $-1.22 *$ & $-1.48^{* *}$ & -0.99 & -1.15 & & 0.44 & 0.17 & & 0.04 \\
\hline Incidence & & $(0.48)$ & $(0.54)$ & $(0.53)$ & $(0.66)$ & & $(0.33)$ & $(0.37)$ & & $(0.51)$ \\
\hline Sub-Saharan & & & $-1.59 *$ & -0.29 & $-2.21 * *$ & & & $-1.45^{* * *}$ & $-1.28 *$ & $-1.47^{*}$ \\
\hline Africa & & & $(0.72)$ & $(0.50)$ & $(0.77)$ & & & $(0.44)$ & $(0.51)$ & $(0.60)$ \\
\hline Latin America & & & 0.02 & & -0.25 & & & $-1.29 * *$ & $-0.97 *$ & $-1.31 *$ \\
\hline and Caribbean & & & $(0.56)$ & & $(0.64)$ & & & $(0.41)$ & $(0.40)$ & $(0.50)$ \\
\hline East Asia and & & & $2.03 * *$ & $2.32 * * *$ & 1.48 & & & 0.64 & & 0.47 \\
\hline Pacific & & & $(0.78)$ & $(0.43)$ & $(0.96)$ & & & $(0.46)$ & & $(0.72)$ \\
\hline Constant & -2.47 & -5.71 & 2.11 & $2.95^{* * *}$ & -1.64 & 1.78 & 0.33 & $4.25^{*}$ & $6.70^{* * *}$ & 3.56 \\
\hline & $(2.42)$ & (2.95) & $(3.01)$ & $(0.86)$ & (3.49) & $(1.27)$ & (1.68) & $(1.90)$ & $(2.03)$ & (2.56) \\
\hline Observations & 1164 & 779 & 779 & 1697 & 779 & 684 & 556 & 556 & 903 & 556 \\
\hline R-squared & 0.21 & 0.4 & 0.34 & 0.19 & 0.20 & 0.72 & 0.77 & 0.75 & 0.51 & 0.25 \\
\hline \multicolumn{11}{|l|}{ First Stage Results } \\
\hline Under identification test: & & & & & & & & & & \\
\hline Kleibergen-Paap rk LM statistic & 14.6 & 14.9 & 19.1 & 16.1 & -- & 10.4 & 11.9 & 16.4 & 10.8 & -- \\
\hline $\begin{array}{l}\text { Weak identification test: } \\
\text { Kleibergen-Paap rk Wald F statistic }\end{array}$ & 39.4 & 45 & 51.9 & 40.3 & -- & 127.5 & 46.7 & 51.7 & 210.8 & -- \\
\hline Stock-Yogo weak ID test critical values: & & & & & & & & & & \\
\hline TSLS 10\% maximal IV relative bias: & 16.38 & 16.38 & 16.38 & 16.38 & -- & 16.38 & 16.38 & 16.38 & 16.38 & -- \\
\hline Maximal IV size distortion 20\%: & 6.66 & 6.66 & 6.66 & 6.66 & -- & 6.66 & 6.66 & 6.66 & 6.66 & -- \\
\hline $\begin{array}{l}\text { Test for endogeneity } \\
\text { Durbin-Wu-Hausman test }\end{array}$ & $6.5 *$ & $5.2 *$ & 9.9 ** & $7.8^{* *}$ & -- & 1.2 & 1.2 & $6.6^{* *}$ & 0.1 & -- \\
\hline
\end{tabular}




\section{Appendix D}

Table A4. Treatment Regression and Single-Stage OLS: World Bank Program Lending and Its Effects on Economic Growth, Pre-and Post-Reform Periods, All Developing Countries with Regional and Annual Fixed Effects.

\begin{tabular}{|c|c|c|c|c|c|c|c|c|c|c|}
\hline & \multicolumn{5}{|c|}{ Pre-Reform Period } & \multicolumn{5}{|c|}{ Post-Reform Period } \\
\hline & $\begin{array}{c}\text { 1981-1998 } \\
\text { Only } \\
\text { Economic } \\
\text { Factors }\end{array}$ & $\begin{array}{l}\text { 1981-1998 } \\
\text { Adds } \\
\text { Political } \\
\text { Controls }\end{array}$ & $\begin{array}{l}\text { 1981-1998 } \\
\text { Adds } \\
\text { Regional } \\
\text { Controls }\end{array}$ & $\begin{array}{c}\text { 1981-1998 } \\
\text { Only Sign. } \\
\text { Results }\end{array}$ & $\begin{array}{l}\text { 1981-1998 } \\
\text { Single-Stage } \\
\text { OLS }\end{array}$ & $\begin{array}{c}\text { 1999-2009 } \\
\text { Only Econ } \\
\text { Factors }\end{array}$ & $\begin{array}{c}\text { 1999-2009 } \\
\text { Adds Pol } \\
\text { Controls }\end{array}$ & $\begin{array}{c}\text { 1999-2009 } \\
\text { Adds Reg } \\
\text { Controls }\end{array}$ & $\begin{array}{c}\text { 1999-2009 } \\
\text { Only Sign. } \\
\text { Results }\end{array}$ & $\begin{array}{c}\text { 1999-2009 } \\
\text { Only Sign. } \\
\text { Results }\end{array}$ \\
\hline Under WB & -0.22 & $-4.31 * *$ & $-4.74 * * *$ & -0.31 & 0.63 & $-2.90 * *$ & $-2.89 * *$ & $-2.99 * *$ & $-5.32 * * *$ & 0.36 \\
\hline PL or Not & $(0.41)$ & $(1.43)$ & $(1.00)$ & $(0.50)$ & $(0.34)$ & $(1.08)$ & $(1.10)$ & $(0.92)$ & $(0.56)$ & $(0.32)$ \\
\hline Log of GDP per Capita & $\begin{array}{c}0.60^{* * *} \\
(0.13)\end{array}$ & $\begin{array}{l}0.81^{* * *} \\
(0.18)\end{array}$ & $\begin{array}{l}0.39 * \\
(0.18)\end{array}$ & $\begin{array}{l}0.36^{* *} \\
(0.11)\end{array}$ & $\begin{array}{c}0.32 \\
(0.22)\end{array}$ & $\begin{array}{c}0.14 \\
(0.10)\end{array}$ & $\begin{array}{l}0.26^{*} \\
(0.12)\end{array}$ & $\begin{array}{c}0.15 \\
(0.11)\end{array}$ & & $\begin{array}{l}0.13 \\
(0.16)\end{array}$ \\
\hline Inflation & $\begin{array}{c}-0.00 * \\
(0.00)\end{array}$ & $\begin{array}{l}-0.00^{* *} \\
(0.00)\end{array}$ & $\begin{array}{c}-0.00^{* *} \\
(0.00)\end{array}$ & $\begin{array}{l}-0.00 \\
(0.00)\end{array}$ & $\begin{array}{c}-0.00 * * * \\
(0.00)\end{array}$ & $\begin{array}{c}0.03 \\
(0.02)\end{array}$ & $\begin{array}{c}0.01 \\
(0.02)\end{array}$ & $\begin{array}{c}0.01 \\
(0.02)\end{array}$ & & $\begin{array}{c}0.01 \\
(0.02)\end{array}$ \\
\hline Domestic Credit & $\begin{array}{l}-0.00 \\
(0.01)\end{array}$ & $\begin{array}{l}-0.01 \\
(0.01)\end{array}$ & $\begin{array}{c}-0.02 * * \\
(0.01)\end{array}$ & $\begin{array}{l}-0.01 \\
(0.01)\end{array}$ & $\begin{array}{l}-0.02 \\
(0.01)\end{array}$ & $\begin{array}{l}0.00 \\
(0.00)\end{array}$ & $\begin{array}{l}-0.00 \\
(0.00)\end{array}$ & $\begin{array}{l}-0.00 \\
(0.00)\end{array}$ & & $\begin{array}{l}-0.00 \\
(0.01)\end{array}$ \\
\hline $\begin{array}{l}\text { Total Debt } \\
\text { Service }\end{array}$ & $\begin{array}{l}-0.10^{*} \\
(0.05)\end{array}$ & $\begin{array}{l}-0.13^{* *} \\
(0.05)\end{array}$ & $\begin{array}{l}-0.13^{* *} \\
(0.05)\end{array}$ & $-0.12 * *$ & $\begin{array}{c}-0.12 * \\
(0.05)\end{array}$ & 0.00 & 0.01 & 0.02 & & 0.01 \\
\hline Debt forgiveness & $\begin{array}{c}0.00 \\
(0.00)\end{array}$ & $\begin{array}{c}(0.00) \\
0.00 \\
(0.00)\end{array}$ & $\begin{array}{c}(0.05) \\
0.00 \\
(0.00)\end{array}$ & & $\begin{array}{c}(0.05) \\
0.00 \\
(0.00)\end{array}$ & $\begin{array}{l}(0.0 .0) \\
-0.00 \\
(0.00)\end{array}$ & $\begin{array}{l}(0.02) \\
-0.00 \\
(0.00)\end{array}$ & $\begin{array}{l}(0.02) \\
-0.00 \\
(0.00)\end{array}$ & & $\begin{array}{l}(0.02) \\
-0.00 \\
(0.00)\end{array}$ \\
\hline $\begin{array}{l}\text { Net Financial } \\
\text { Flows }\end{array}$ & $\begin{array}{c}0.00 \\
(0.00)\end{array}$ & $\begin{array}{c}0.00 \\
(0.00)\end{array}$ & $\begin{array}{l}-0.00 \\
(0.00)\end{array}$ & & $\begin{array}{c}0.00 \\
(0.00)\end{array}$ & $\begin{array}{l}-0.00 \\
(0.00)\end{array}$ & $\begin{array}{l}-0.00 \\
(0.00)\end{array}$ & $\begin{array}{l}-0.00 \\
(0.00)\end{array}$ & & $\begin{array}{l}-0.00 \\
(0.00)\end{array}$ \\
\hline Openness & $\begin{array}{c}0.03^{* * *} \\
(0.01)\end{array}$ & $\begin{array}{c}0.03^{* * *} \\
(0.01)\end{array}$ & $\begin{array}{l}0.02 * \\
(0.01)\end{array}$ & $\begin{array}{c}0.02 * * * \\
(0.01)\end{array}$ & $\begin{array}{c}0.02 \\
(0.01)\end{array}$ & $\begin{array}{l}0.01 * \\
(0.00)\end{array}$ & $\begin{array}{l}0.01 * * \\
(0.00)\end{array}$ & $\begin{array}{c}0.00 \\
(0.00)\end{array}$ & & $\begin{array}{c}0.00 \\
(0.01)\end{array}$ \\
\hline Under IMF PL & $\begin{array}{l}-0.13 \\
(0.32)\end{array}$ & $\begin{array}{c}0.51 \\
(0.35)\end{array}$ & $\begin{array}{c}0.63 \\
(0.35)\end{array}$ & & $\begin{array}{c}0.51 \\
(0.42)\end{array}$ & $\begin{array}{c}0.13 \\
(0.29)\end{array}$ & $\begin{array}{c}0.47 \\
(0.29)\end{array}$ & $\begin{array}{c}0.41 \\
(0.29)\end{array}$ & & $\begin{array}{c}0.45 \\
(0.36)\end{array}$ \\
\hline Human Capital & $\begin{array}{l}-0.10 \\
(0.59)\end{array}$ & $\begin{array}{l}-0.05 \\
(0.65)\end{array}$ & $\begin{array}{l}-0.35 \\
(0.64)\end{array}$ & & $\begin{array}{l}-0.49 \\
(0.89)\end{array}$ & $\begin{array}{c}0.46 \\
(0.37)\end{array}$ & $\begin{array}{l}1.18^{* *} \\
(0.41)\end{array}$ & $\begin{array}{l}1.24^{* *} \\
(0.40)\end{array}$ & $\begin{array}{l}-0.29 \\
(0.30)\end{array}$ & $\begin{array}{c}1.23 \\
(0.67)\end{array}$ \\
\hline $\begin{array}{c}\text { Capital Stock per } \\
\text { Worker }\end{array}$ & $\begin{array}{c}-0.00 * * * \\
(0.00)\end{array}$ & $\begin{array}{c}-0.00 * * * \\
(0.00)\end{array}$ & $\begin{array}{c}-0.00^{* * *} \\
(0.00)\end{array}$ & $\begin{array}{c}-0.00 * * * \\
(0.00)\end{array}$ & $\begin{array}{c}-0.00^{* * *} \\
(0.00)\end{array}$ & $\begin{array}{c}-0.00^{* *} \\
(0.00)\end{array}$ & $\begin{array}{c}-0.00 * * * \\
(0.00)\end{array}$ & $\begin{array}{c}-0.00 * * * \\
(0.00)\end{array}$ & $\begin{array}{c}-0.00 * * \\
(0.00)\end{array}$ & $\begin{array}{c}-0.00^{* *} \\
(0.00)\end{array}$ \\
\hline Exchange Rates & $\begin{array}{l}-0.00 \\
(0.00)\end{array}$ & $\begin{array}{l}-0.00 \\
(0.00)\end{array}$ & $\begin{array}{c}-0.00 * \\
(0.00)\end{array}$ & $\begin{array}{l}-0.00 \\
(0.00)\end{array}$ & $\begin{array}{l}-0.00 \\
(0.00)\end{array}$ & $\begin{array}{l}0.00 * * \\
(0.00)\end{array}$ & $\begin{array}{l}-0.00 \\
(0.00)\end{array}$ & $\begin{array}{l}-0.00 \\
(0.00)\end{array}$ & & $\begin{array}{l}-0.00 \\
(0.00)\end{array}$ \\
\hline Foreign & $0.30^{* * *}$ & $0.31^{* * *}$ & $0.29 * * *$ & $0.26^{* * *}$ & $0.31^{* * *}$ & $0.12 * *$ & $0.11^{* *}$ & $0.10^{*}$ & $0.07 *$ & 0.10 \\
\hline Currency Reserves & $(0.06)$ & $(0.06)$ & $(0.06)$ & $(0.05)$ & $(0.08)$ & $(0.04)$ & $(0.04)$ & $(0.04)$ & $(0.03)$ & $(0.06)$ \\
\hline $\begin{array}{c}\text { Population } \\
\text { change }\end{array}$ & $\begin{array}{c}0.17 \\
(0.30)\end{array}$ & $\begin{array}{l}0.81^{*} \\
(0.38)\end{array}$ & $\begin{array}{l}0.85^{*} \\
(0.37)\end{array}$ & $\begin{array}{c}0.17 \\
(0.21)\end{array}$ & $\begin{array}{l}0.78^{*} \\
(0.37)\end{array}$ & $\begin{array}{l}-0.02 \\
(0.15)\end{array}$ & $\begin{array}{l}-0.08 \\
(0.19)\end{array}$ & $\begin{array}{c}0.14 \\
(0.18)\end{array}$ & & $\begin{array}{c}0.11 \\
(0.25)\end{array}$ \\
\hline Corruption & & $\begin{array}{c}0.19 \\
(0.21)\end{array}$ & $\begin{array}{c}0.15 \\
(0.21)\end{array}$ & & $\begin{array}{c}0.17 \\
(0.28)\end{array}$ & & $\begin{array}{c}-0.33 * \\
(0.17)\end{array}$ & $\begin{array}{l}-0.22 \\
(0.17)\end{array}$ & & $\begin{array}{l}-0.22 \\
(0.22)\end{array}$ \\
\hline
\end{tabular}


Table A4. Cont.

\begin{tabular}{|c|c|c|c|c|c|c|c|c|c|c|}
\hline & \multicolumn{5}{|c|}{ Pre-Reform Period } & \multicolumn{5}{|c|}{ Post-Reform Period } \\
\hline & $\begin{array}{c}\text { 1981-1998 } \\
\text { Only } \\
\text { Economic } \\
\text { Factors }\end{array}$ & $\begin{array}{l}\text { 1981-1998 } \\
\text { Adds } \\
\text { Political } \\
\text { Controls }\end{array}$ & $\begin{array}{c}\text { 1981-1998 } \\
\text { Adds } \\
\text { Regional } \\
\text { Controls }\end{array}$ & $\begin{array}{c}\text { 1981-1998 } \\
\text { Only Sign. } \\
\text { Results }\end{array}$ & $\begin{array}{l}\text { 1981-1998 } \\
\text { Single-Stage } \\
\text { OLS }\end{array}$ & $\begin{array}{c}\text { 1999-2009 } \\
\text { Only Econ } \\
\text { Factors }\end{array}$ & $\begin{array}{c}\text { 1999-2009 } \\
\text { Adds Pol } \\
\text { Controls }\end{array}$ & $\begin{array}{c}\text { 1999-2009 } \\
\text { Adds Reg } \\
\text { Controls }\end{array}$ & $\begin{array}{c}\text { 1999-2009 } \\
\text { Only Sign. } \\
\text { Results }\end{array}$ & $\begin{array}{c}\text { 1999-2009 } \\
\text { Only Sign } \\
\text { Results }\end{array}$ \\
\hline Bureaucratic & & -0.08 & 0.21 & & 0.22 & & -0.42 & $-0.49 *$ & -0.28 & -0.44 \\
\hline Quality & & $(0.21)$ & $(0.22)$ & & $(0.32)$ & & $(0.23)$ & $(0.23)$ & $(0.19)$ & $(0.30)$ \\
\hline Law and Order & & $\begin{array}{c}0.05 \\
(0.19)\end{array}$ & $\begin{array}{l}-0.00 \\
(0.19)\end{array}$ & & $\begin{array}{l}-0.02 \\
(0.20)\end{array}$ & & $\begin{array}{l}0.29 * \\
(0.13)\end{array}$ & $\begin{array}{c}0.13 \\
(0.14)\end{array}$ & & $\begin{array}{c}0.13 \\
(0.20)\end{array}$ \\
\hline Level of & & 0.05 & -0.00 & & -0.02 & & -0.09 & -0.06 & & -0.06 \\
\hline Democracy & & $(0.06)$ & $(0.06)$ & & $(0.07)$ & & $(0.05)$ & $(0.05)$ & & $(0.07)$ \\
\hline Military Regimes & & $\begin{array}{l}-0.30 \\
(0.75)\end{array}$ & $\begin{array}{l}-0.70 \\
(0.75)\end{array}$ & & $\begin{array}{l}-0.55 \\
(1.06)\end{array}$ & & $\begin{array}{l}-1.46^{*} \\
(0.70)\end{array}$ & $\begin{array}{c}-1.96^{* *} \\
(0.64)\end{array}$ & $\begin{array}{l}-0.73 \\
(0.74)\end{array}$ & $\begin{array}{c}-1.96^{* *} \\
(0.66)\end{array}$ \\
\hline Workers' Rights & & $\begin{array}{l}-0.05 \\
(0.27)\end{array}$ & $\begin{array}{l}-0.19 \\
(0.27)\end{array}$ & & $\begin{array}{l}-0.11 \\
(0.32)\end{array}$ & & $\begin{array}{l}-0.15 \\
(0.25)\end{array}$ & $\begin{array}{l}-0.15 \\
(0.25)\end{array}$ & & $\begin{array}{l}-0.14 \\
(0.32)\end{array}$ \\
\hline Civil War & & -0.82 & $-0.96^{*}$ & -1.13 & -1.13 & & 0.43 & 0.11 & & 0.03 \\
\hline Incidence & & $(0.44)$ & $(0.47)$ & $(0.61)$ & $(0.66)$ & & $(0.31)$ & $(0.33)$ & & $(0.51)$ \\
\hline Cold War & & & $\begin{array}{c}0.64 \\
(0.78)\end{array}$ & & $\begin{array}{l}1.37 \\
(1.01)\end{array}$ & & & & & \\
\hline Sub-Saharan & & & $-1.99 * *$ & $-1.27^{* *}$ & $-2.10^{* *}$ & & & $-1.46^{* * *}$ & $-1.45^{* * *}$ & $-1.41 *$ \\
\hline Africa & & & $(0.66)$ & $(0.43)$ & $(0.75)$ & & & $(0.38)$ & $(0.31)$ & $(0.58)$ \\
\hline Latin America and & & & -0.19 & & -0.15 & & & $-1.25^{* *}$ & $-1.65^{* * *}$ & $-1.27^{*}$ \\
\hline Caribbean & & & $(0.50)$ & & $(0.66)$ & & & $(0.39)$ & $(0.3)$ & $(0.49)$ \\
\hline $\begin{array}{c}\text { East Asia and } \\
\text { Pacific }\end{array}$ & & & $\begin{array}{c}2.14^{* * * *} \\
(0.64)\end{array}$ & $\begin{array}{l}0.97^{*} \\
(0.43)\end{array}$ & $\begin{array}{l}1.58 \\
(0.97)\end{array}$ & & & $\begin{array}{c}0.55 \\
(0.42)\end{array}$ & & $\begin{array}{c}0.48 \\
(0.76)\end{array}$ \\
\hline Constant & $\begin{array}{l}-5.55^{*} \\
(2.36)\end{array}$ & $\begin{array}{c}-7.15^{*} \\
(3.04)\end{array}$ & $\begin{array}{l}0.07 \\
(2.86)\end{array}$ & $\begin{array}{l}-1.39 \\
(1.30)\end{array}$ & $\begin{array}{l}-1.37 \\
(3.54)\end{array}$ & $\begin{array}{l}3.00 * \\
(1.48)\end{array}$ & $\begin{array}{c}1.27 \\
(1.91)\end{array}$ & $\begin{array}{l}3.89 * \\
(1.83)\end{array}$ & & $\begin{array}{l}3.30 \\
(2.57)\end{array}$ \\
\hline Observations & 1164 & 779 & 779 & 1364 & 779 & 684 & 556 & 556 & & 556 \\
\hline R-squared & & & & & 0.20 & & & & & 0.25 \\
\hline
\end{tabular}

$p>\mid \mathrm{z} 0.05^{*}, 0.01^{* *}, 0.001 * * *$ All models were estimated with two-tailed significant tests and included time fixed effects. Robust standard errors in parentheses. 


\section{References}

Abouharb, M. Rodwan, and David Cingranelli. 2004. Human Rights and Structural Adjustment: The Importance of Selection. In Understanding Human Rights Violations: New Systematic Studies. Edited by Sabine C. Carey and Steven C. Poe. Aldershot: Ashgate Publishing, pp. 127-46.

Abouharb, M. Rodwan, and David Cingranelli. 2006. The Human Rights Effects of World Bank Structural Adjustment Lending, 1981-2000. International Studies Quarterly 50: 233-62. [CrossRef]

Abouharb, M. Rodwan, and David Cingranelli. 2007. Human Rights and Structural Adjustment. Cambridge: Cambridge University Press.

Abouharb, M. Rodwan, and David Cingranelli. 2009. IMF Programs and Human Rights, 1981-2003. Review of International Organizations 4: 47-72. [CrossRef]

Acemoglu, Daron, and James A. Robinson. 2012. Why Nations Fail. The Origins of Power, Prosperity, and Poverty. New York: Crown Business.

Acemoglu, Daron, Simon Johnson, and James A. Robinson. 2005. Institutions as a fundamental cause of long run economic growth. In Handbook of Economic Growth. Edited by Philippe Aghion and Steven N. Durlauf. Amsterdam: Elsevier B.V., vol. 1A, pp. 386-472.

Alexander, Nancy. 2005. The Roles of the IMF, the World Bank, and the WTO in Liberalization and Privatization of the Water Services Sector. Citizens' Network on Essential Services. Available online: www.servicesforall.org (accessed on 27 April 2019).

Arndt, Channing, Sam Jones, and Finn Tarp. 2010. Aid and Growth: Have We Come Full Circle? Journal of Globalization and Development 1: 1-27. [CrossRef]

Atoyan, Ruben, and Patrick Conway. 2006. Evaluating the Impact of IMF Programs: A Comparison of Matching and Instrumental-variable Estimators. Review of International Organizations 1: 99-124. [CrossRef]

Barro, Robert J. 1997. Determinants of Economic Growth: A Cross-Country Empirical Study. Cambridge and London: MIT Press.

Barro, Robert J. 2003. Determinants of Economic Growth in a Panel of Countries. Annals of Economics and Finance 4: 231-74.

Barro, Robert J., and Jong-Wha Lee. 2010. A New Data Set of Educational Attainment in the World, 1950-2010. Journal of Development Economics 104: 184-98. [CrossRef]

Bas, Muhammet A., and Randall W. Stone. 2014. Adverse Selection and Growth under IMF Programs. Review of International Organization 9: 1-28. [CrossRef]

Baum, Christopher F., Mark E. Schaffer, and Steven Stillman. 2007. Enhanced Routines for Instrumental Variables/GMM Estimation and Testing. Boston College Economics Working Paper No. 667. Available online: http://fmwww.bc.edu/ec-p/wp667.pdf (accessed on 15 June 2017).

Baum, Christopher F., Mark E. Schaffer, and Steven Stillman. 2010. Ivreg2: Stata Module for Extended Instrumental Variables/2SLS, GMM and AC/HAC, LIML and k-Class Regression. Available online: http: //ideas.repec.org/c/boc/bocode/s425401.html (accessed on 18 June 2017).

Bird, Graham, and Dane Rowlands. 2001. World Bank Lending and Other Financial Flows: Is There a Connection? The Journal of Development Studies 37: 83-103. [CrossRef]

Birdsall, Nancy, and Juan Luis Londoño. 1997. Asset Inequality Matters: An Assessment of the World Bank's Approach to Poverty Reduction. The American Economic Review 87: 32-37.

Blackmon, Pamela. 2008. Rethinking Poverty through the Eyes of the International Monetary Fund and the World Bank. International Studies Review 10: 179-202. [CrossRef]

Blumenthal, Erwin M. 1982. Zaire: Rapport Sur la Crédibilité Financière Internationale. In Emmanual Dungia Mobutu et l'Argent du Zaire: Les Révélations d'un Diplomate Ex-Agent des Services Secrets (annexe 2). Paris: L'Harmattan, pp. 136-55.

Borensztein, Eduardo, Jose De Gregorio, and Jong-Wha Lee. 1998. How does foreign direct investment affect economic growth? Journal of International Economics 45: 115-35.

Bourguignon, François, and Mark Sundberg. 2007. Aid Effectiveness: Opening the Black Box. The American Economic Review 97: 316-21. [CrossRef]

Burnside, Craig, and David Dollar. 2000. Aid, Policies, and Growth. The American Economic Review 90: 847-68. [CrossRef] 
Burnside, Craig, and David Dollar. 2004a. Aid, Policies, and Growth: Revisiting the Evidence. World Bank Policy Research Working Paper No. 3251. Washington, DC, USA: World Bank.

Burnside, Craig, and David Dollar. 2004b. Aid, Policies, and Growth: Reply. The American Economic Review 94: 781-84. [CrossRef]

Butkiewicz, James L., and Halit Yanikkaya. 2005. The Effects of IMF and World Bank Lending on Long-Run Economic Growth: An Empirical Analysis. World Development 33: 371-91. [CrossRef]

CIRI Human Rights Data Project. 2014. Available online: http://www.humanrightsdata.com/2014/ (accessed on 27 March 2014).

Chenery, Hollis B., and Adam M. Strout. 1966. Foreign Assistance and Economic Development. American Economic Review 56: 679-733.

Cingranelli, David L., David L. Richards, and K. Chad Clay. 2014. The CIRI Human Rights Dataset. Available online: http://www.humanrightsdata.com (accessed on 27 March 2014).

Clemens, Michael A., and Michael Kremer. 2016. The New Role for the World Bank. Journal of Economic Perspectives 30: 53-76. [CrossRef]

Clemens, Michael, Steven Radelet, and Rikhil R. Bhavnani. 2006. Counting Chickens when They Hatch: The Short-Term Effect of Aid on Growth. Working Paper No. 44. Washington, DC, USA: Centre for Global Development.

Clements, Benedict, Rina Bhattacharya, and Toan Quoc Nguyen. 2005. Can Debt Relief Boost Growth in Poor Countries? Economic Issues No. 34 (April). Available online: http://www.imf.org/External/Pubs/FT/issues/ issues34/ (accessed on 17 March 2016).

Collier, Paul. 2008. The Bottom Billion: Why the Poorest Countries Are Failing and What Can Be Done about It. Oxford: Oxford University Press.

Collier, Paul, and David Dollar. 2002. Aid Allocation and Poverty reduction. Journal of Development Studies 46: 1475-500. [CrossRef]

Collier, Paul, Patrick Guillaumont, Sylviane Guillaumont, and Jan Willem Gunning. 1997. Redesigning Conditionality. World Development 25: 1399-407. [CrossRef]

Council of Economic Advisors. 2015. The Economic Benefits of U.S. Trade; Washington, DC: Executive Office of the President of the United States. Available online: https://obamawhitehouse.archives.gov/sites/default/files/ docs/cea_trade_report_final_non-embargoed_v2.pdf (accessed on 18 June 2017).

Cull, Robert, and Laurie Effron. 2008. World Bank Lending and Financial Sector Development. The World Bank Economic Review 22: 315-43. [CrossRef]

Dalgaard, Carl-Johan., Henrik Hansen, and Finn Tarp. 2004. On the Empirics of Foreign Aid and Growth. The Economic Journal 114: 191-216. [CrossRef]

De Mesquita, Bruce Bueno, Alastair Smith, James D. Morrow, and Randolph M. Siverson. 2005. The Logic of Political Survival. Cambridge: MIT Press.

Dollar, David, and Jakob Svensson. 2000. What Explains the Success or Failure of Structural Adjustment Programmes. The Economic Journal 110: 894-917. [CrossRef]

Domar, Evsey D. 1946. Capital Extension, Rate of Growth and Employment. Econometrica 14: 137-47. [CrossRef]

Donnelly, Jack. 2003. Universal Human Rights in Theory and Practice, 2nd ed. Ithaca: Cornell University Press.

Dreher, Axel. 2006. IMF and Economic Growth: The Effects of Programs, Loans, and Compliance with Conditionality. World Development 34: 769-88. [CrossRef]

Dreher, Axel, and Jan-Egbert Sturm. 2012. Do the IMF and the World Bank Influence Voting in the UN General Assembly? Public Choice 151: 363-97. [CrossRef]

Dreher, Axel, Jan-Egbert Sturm, and James Raymond Vreeland. 2009. Development Aid and International Politics: Does Membership on the UN Security Council Influence World Bank Decisions. Journal of Development Economics 88: 1-18. [CrossRef]

Driscoll, Ruth, and Alison Evans. 2005. Second-Generation Poverty Reduction Strategies: New Opportunities and Emerging Issues. Development Policy Review 23: 5-25. [CrossRef]

Easterly, William. 2003. The Effect of International Monetary Fund and World Bank Programs on Poverty. In emphManaging Currency Crises in Emerging Markets. Edited by Michael P. Dooley and Jeffrey A. Frankel. Chicago: University of Chicago Press, pp. 361-82.

Easterly, William. 2005. What Did Structural Adjustment Adjust? The Association of Policies and Growth with Repeated IMF and World Bank Adjustment loans. Journal of Development Economics 76: 1-22. [CrossRef] 
Easterly, William. 2006. Why the West's Efforts to Aid the Rest Have Done So Much Ill and So Little Good. New York: Penguin.

Easterly, William, Ross Levin, and David Roodman. 2004. Aid, Policies and Growth: Comment. American Economic Review 94: 774-80. [CrossRef]

Feenstra, Robert C., Robert Inklaar, and Marcel Timmer. 2013. The Next Generation of the Penn World Table. NBER Working Paper No. 19255. Cambridge, MA, USA: NBER.

Feyzioglu, Tarhan, Vinaya Swaroop, and Min Zhu. 1998. A Panel Data Analysis of the Fungibility of Foreign Aid. The World Bank Economic Review 12: 29-58. [CrossRef]

Foreign and Commonwealth Office. 2018. Combatting Corruption: Objectives 2017 to 2018; United Kingdom Government. Available online: https:/www.gov.uk/government/publications/official-developmentassistance-oda-fco-programme-spend-objectives-2017-to-2018/combatting-corruption-objectives-2017-to2018 (accessed on 27 April 2019).

Frey, Bruno S., and Friedrich Schneider. 1986. Competing Models of International Lending Activity. Journal of Development Economics 20: 225-45. [CrossRef]

Geddes, Rick, Dean Lueck, and Sharon Tennyson. 2012. Human Capital Accumulation and the Expansion of Women's Economic Rights. Journal of Law and Economics 55: 839-67. [CrossRef]

Gamazo, Carolina, and Asier Andrés. 2018. World Bank/IFC Turns a Blind Eye to Corruption in Central America. Available online: https:/www.no-ficcion.com/project/world-bank-ifc-the-silent-partner-of-corruption-incentral-america (accessed on 27 April 2019).

Gleditsch, Nils Petter, Peter Wallensteen, Mikael Eriksson, Margareta. Sollenberg, and Håvard Strand. 2002. Armed Conflict 1946-2001: A New Dataset. Journal of Peace Research 39: 615-37. [CrossRef]

Grusky, Sara. 2001. IMF Forces Water Privatization on Poor Countries. Globalization Challenge Initiative. Available online: www.ige.org (accessed on 27 April 2019).

Guillaumont, Patrick, and Rachid Laajaj. 2006. When Instability Increases the Effectiveness of Aid Projects. World Bank Policy Research Paper No. 4034. Washington, DC, USA: World Bank.

Hanlon, Joseph. 2004. Do donors promote corruption?: The case of Mozambique. Third World Quarterly 25: 747-63. [CrossRef]

Hansen, Henrik, and Finn Tarp. 2000. Aid Effectiveness Disputed. Journal of International Development 12: 375-98. [CrossRef]

Hansen, Henrik, and Finn Tarp. 2001. Aid and Growth Regressions. Journal of Development Economics 62: 547-70.

Harrod, Roy F. 1939. An Essay in Dynamic Theory. The Economic Journal 49: 14-33. [CrossRef]

Harrigan, Jane, and Paul Mosley. 1991. Assessing the Impact of World Bank Structural Development Lending 1980-1987. The Journal of Development Studies 27: 63-94. [CrossRef]

Hensel, Paul R. 2018. ICOW Colonial History Data Set, Version 1.1. Available online: http://www.paulhensel.org/ icowcol.html (accessed on 27 March 2018).

Heston, Alan, Robert Summers, and Bettina Aten. 2011. Penn World Table Version 7.0, Center for International Comparisons of Production, Income and Prices at the University of Pennsylvania, June 2011. Available online: https://www.rug.nl/ggdc/productivity/pwt/pwt-releases/pwt-7.0 (accessed on 15 October 2016).

Hutchison, M. M., and I. Noy. 2003. Macroeconomic effects of IMF-sponsored programs in Latin America: Output Costs, Program Recidivism and the Vicious Cycle of Failed Stabilization. Journal of International Money and Finance 22: 991-1014. [CrossRef]

Independent Evaluation Group. 2006. Debt Relief for the Poorest: An Evaluation Update of the HIPC Initiative. Washington, DC: The World Bank.

Independent Evaluation Group. 2010. Poverty Reduction Support Credits: An Evaluation of World Bank Support. Washington, DC: The World Bank.

International Monetary Fund. 2013. The Multilateral Debt Relief Initiative. Available online: http://www.imf.org/ external/np/exr/facts/mdri.htm (accessed on 21 September 2013).

Irandoust, Manuchehr, and Johan Ericsson. 2005. Foreign Aid, Domestic Savings, and Growth in LDCs: An Application of Likelihood-based Panel Integration. Economic Modelling 22: 616-27. [CrossRef]

Jayarajah, Carl A. B., William H. Branson, and Binayak Sen. 1996. The social Dimensions of Adjustment: International Monetary Fund Experience, 1980-1993. An International Monetary Fund Operations Evaluation Study. Washington, DC: The World Bank. 
Kenny, Charles. 2008. What Is Effective Aid? How Would Donors Allocate It? The European Journal of Development Research 20: 330-46.

Kilby, Christopher. 2009. The Political Economy of Conditionality: An Empirical Analysis of World Bank Loan Disbursements. Journal of Development Economics 89: 51-61. [CrossRef]

Killick, Tony. 1995. IMF Programmes in Developing Countries: Design and Impact. New York: Routledge for Overseas Development Institute.

Killick, Tony. 2004. Politics, Evidence and the New Aid Agenda. Development Policy Review 22: 5-29. [CrossRef]

Knack, Stephen, F. Halsey Rogers, and Jac C. Heckelman. 2012. Crossing the Threshold: A Positive Analysis of IBRD Graduation Policy. Review of International Organizations 7: 145-76. [CrossRef]

Mallick, Sushanta, and Tomoe Moore. 2008. Foreign Capital in Growth Model. Review of Development Economics 12: 143-59. [CrossRef]

Marchesi, Silvia, and Emanuela Sirtori. 2011. Is Two Better Than One? The Effects of IMF and World Bank Interaction on Growth. Review of International Organizations 6: 287-306. [CrossRef]

Marshall, Monty G., and Keith Jaggers. 2010. Polity IV Project Political Regim Characteristics and Transitions, 1800-2009. Dataset Users' Manual. Available online: http://www.systemicpeace.org/polity/polity4.htm (accessed on 27 March 2011).

Montinola, Gabriella R. 2010. When Does Aid Conditionality Work? Studies in Comparative International Development 45: 358-82. [CrossRef]

Mosley, Paul. 1987. Overseas Aid. Its defence and Reforms. Sussex: Wheatsheaf Books.

Mosley, Paul, Jane Harrigan, and John Toye. 1995. Aid and Power: The World Bank and Policy Based Lending, Volume 1, Analysis and Policy Proposals, 2nd ed. London: Routledge.

Ndikumana, Leonce, and James K. Boyce. 1998. Congo's Odious Debt: External Borrowing and Capital Flight in Zaire. Development and Change 29: 195-217. [CrossRef]

Elson, Diane. 1991. Male Bias in Macroeconomics: The Case of Structural Adjustment. In Male Bias in the Development Process. Edited by Diane Elson. Manchester: Manchester University Press.

Paloni, Alberto, and Maurizio Zanardi, eds. 2006a. The IMF, World Bank and Policy Reform. London: Routledge.

Paloni, Alberto, and Maurizio Zanardi. 2006b. Can Conditionality Improve Borrower Ownership? In The IMF, World Bank and Policy Reform. Edited by A. Paloni and M. Zanardi. London: Routledge, pp. 256-65.

PRS Group. 2019. Table 3B Researcher's Dataset. In International Country Risk Guide. Washington, DC: PRS Group.

Przeworski, Adam, and James Raymond Vreeland. 2000. The Effects of IMF Programs on Economic Growth. The Journal of Development Economics 62: 385-421. [CrossRef]

Rajan, Raghuram G., and Arvind Subramanian. 2008. Aid and Growth: What Does the Cross-country Evidence Really Show? The Review of Economics and Statistics 90: 643-65. [CrossRef]

Rajan, Raghuram G., and Arvind Subramanian. 2011. Aid, Dutch Disease, and Manufacturing Growth. Journal of Development Economics 94: 106-18. [CrossRef]

Ravallion, Martin. 2016. The World Bank: Why It Is Still Needed and Why It Still Disappoints. Journal of Economic Perspectives 30: 77-94. [CrossRef]

Riddell, Roger C. 2007. Does Foreign Aid Really Work? New York: Oxford.

Ridley, Charles. 1989. The 1980s was a 'lost decade' for development in ... . UPI Archives. December 20. Available online: https://www.upi.com/Archives/1989/12/20/The-1980s-was-a-lost-decade-for-developmentin/6776630133200/ (accessed on 30 April 2019).

Robb, Caroline M. 2002. Can the Poor Influence Policy? Participatory Poverty Assessments in the Developing World, 2nd ed. Washington, DC: World Bank.

Rodrik, Dani. 2006. Goodbye Washington Consensus, Hello Washington Confusion? A Review of the World Bank's Economic Growth in the 1990s: Learning from a Decade of Reform. Journal of Economic Literature 54: 973-87. [CrossRef]

Rogoff, Kenneth. 2003. The IMF Strikes Back. Foreign Policy 134: 39-46. [CrossRef]

Sachs, Jeffrey D. 2005. The End of Poverty: Economic Possibilities for Our Time. New York: Penguin.

Santiso, Carlos. 2001. Good Governance and Aid Effectiveness: The World Bank and Conditionality. The Georgetown Public Policy Review 7: 1-22.

SAPRIN (Structural Adjustment Participatory Review International Network). 2004. Structural Adjustment: The SAPRIN Report: The Policy Roots of Economic Crisis, Poverty, and Inequality. London: Zed Books. 
Staiger, Douglas, and James H. Stock. 1997. Instrumental variables regression with weak instruments. Econometrica 65: 557-86. [CrossRef]

StataCorp. 2015. STATA Base Reference Manual. Release 14. College Station: A Stata Press Publication, StataCorp LP. Stiglitz, Joseph. 2002. Globalization and its Discontents. New York: W.W. Norton.

Stone, Randall L. 2004. The Political Economy of IMF Lending in Africa. American Political Science Review 98: 577-92. [CrossRef]

Strand, Håvard, Lars Wilhelmsen, and Nils Petter Gleditsch. 2005. Armed Conflict Dataset Codebook, Version 3.2; September 9. Available online: http://www.prio.no/cwp/ArmedConflict/ (accessed on 27 March 2011).

Rose-Ackerman, Susan. 1997. The Role of the World Bank in Controlling Corruption. Law and Policy in International Business 29: 93-114.

Tarnoff, Curt, and Larry Nowels. 2005. Foreign Aid: An Introductory Overview of U.S. Programs and Policy. Congressional Research Service Report for Congress. Congressional Research Service. Available online: https://www.fas.org/sgp/crs/row/98-916.pdf (accessed on 2 March 2014).

Vreeland, James Raymond. 2003. The IMF and Economic Development. New York: Cambridge University Press.

Wane, Waly. 2004. The Quality of Foreign Aid: Country Selectivity or Donor Incentives? World Bank Policy Research Working Paper No. 3325. Washington, DC, USA: World Bank.

Weeks, John. 2006. Conditionality, Development Assistance and Poverty. In The IMF, World Bank and Policy Reform. London: Routledge, pp. 256-65.

White, Howard. 2007. The Bangladesh Health Swap: Experience of a New Aid Instrument in Practice. Development Policy Review 25: 451-72. [CrossRef]

Wolfensohn, James D. 2005. Voice for the World's Poor: Selected Speeches and Writings of World Bank President James D. Wolfensohn, 1995-2005. Washington, DC: The World Bank.

World Bank. 1998. Assessing Aid: What Works, What Doesn't, and Why. Washington, DC: Oxford University Press.

World Bank. 2004. The Poverty Reduction Strategy Initiative: An Independent Evaluation of the World Bank's Support Through 2003. Washington, DC: Operations Evaluation Department.

World Bank. 2005. Economic Growth in the 1990s: Learning from a Decade of Reform. Washington, DC: World Bank.

World Bank. 2007. Strengthening World Bank Group Engagement on Governance and Anticorruption. Available online: http://www1.worldbank.org/publicsector/anticorrupt/corecourse2007/GACMaster.pdf (accessed on 27 April 2019).

World Bank. 2015. World Development Indicators. Available online: www.worldbank.org (accessed on 27 March 2015).

World Bank. 2019. What We Do. Available online: http://www.worldbank.org/en/about/what-we-do (accessed on 25 April 2019).

World Bank and International Monetary Fund. 2004. Poverty Reduction Strategy Papers_Progress in Implementation; Washington, DC. Available online: http://siteresources.worldbank.org/INTPRS1/Resources/prsp_program_ 2004.pdf (accessed on 8 July 2012).

World Bank and International Monetary Fund. 2005. The Poverty Reduction Strategy Initiative: Findings from 10 Country Case Studies of World Bank and IMF Support. Washington, DC: World Bank Operations Evaluation Department and International Monetary Fund Independent Evaluation Office.

(C) 2019 by the authors. Licensee MDPI, Basel, Switzerland. This article is an open access article distributed under the terms and conditions of the Creative Commons Attribution (CC BY) license (http://creativecommons.org/licenses/by/4.0/). 